\title{
Quantification and evaluation of atmospheric ammonia emissions with different methods: a case study for the Yangtze River Delta region, China
}

\author{
Yu Zhao ${ }^{1,2}$, Mengchen Yuan ${ }^{1}$, Xin Huang ${ }^{3}$, Feng Chen ${ }^{4}$, and Jie Zhang ${ }^{4}$ \\ ${ }^{1}$ State Key Laboratory of Pollution Control \& Resource Reuse and School of the Environment, Nanjing University, \\ 163 Xianlin Ave., Nanjing, Jiangsu 210023, China \\ ${ }^{2}$ Jiangsu Collaborative Innovation Center of Atmospheric Environment and Equipment Technology (CICAEET), \\ Nanjing University of Information Science \& Technology, Jiangsu 210044, China \\ ${ }^{3}$ School of Atmospheric Science, Nanjing University, 163 Xianlin Ave., Nanjing, Jiangsu 210023, China \\ ${ }^{4}$ Jiangsu Provincial Academy of Environmental Science, 176 North Jiangdong Rd., Nanjing, Jiangsu 210036, China
}

Correspondence: Yu Zhao (yuzhao@nju.edu.cn)

Received: 31 July 2019 - Discussion started: 12 November 2019

Revised: 28 February 2020 - Accepted: 11 March 2020 - Published: 9 April 2020

\begin{abstract}
To explore the effects of data and method on emission estimation, two inventories of $\mathrm{NH}_{3}$ emissions of the Yangtze River Delta (YRD) region in eastern China were developed for 2014 based on constant emission factors (E1) and those characterizing agricultural processes (E2). The latter derived the monthly emission factors and activity data integrating the local information of soil, meteorology, and agricultural processes. The total emissions were calculated to be 1765 and $1067 \mathrm{Gg}$ with E1 and E2, respectively, and clear differences existed in seasonal and spatial distributions. Elevated emissions were found in March and September in E2, attributed largely to the increased top dressing fertilization and to the enhanced $\mathrm{NH}_{3}$ volatilization under high temperature, respectively. A relatively large discrepancy between the inventories existed in the northern YRD with abundant croplands. With the estimated emissions $38 \%$ smaller in E2, the average of simulated $\mathrm{NH}_{3}$ concentrations with an air quality model using E2 was $27 \%$ smaller than that using E1 at two ground sites in the YRD. At the suburban site in Pudong, Shanghai (SHPD), the simulated $\mathrm{NH}_{3}$ concentrations with E1 were generally larger than observations, and the modeling performance was improved, indicated by the smaller normalized mean errors (NMEs) when E2 was applied. In contrast, very limited improvement was found at the urban site JSPAES, as E2 failed to improve the emission estimation of transportation and residential activities. Compared to $\mathrm{NH}_{3}$,
\end{abstract}

the modeling performance for inorganic aerosols was better for most cases, and the differences between the simulated concentrations with $\mathrm{E} 1$ and $\mathrm{E} 2$ were clearly smaller, at $7 \%$, $3 \%$, and $12 \%$ (relative to $\mathrm{E} 1$ ) for $\mathrm{NH}_{4}^{+}, \mathrm{SO}_{4}^{2-}$, and $\mathrm{NO}_{3}^{-}$, respectively. Compared to the satellite-derived $\mathrm{NH}_{3}$ column, application of E2 significantly corrected the overestimation in vertical column density for January and October with E1, but it did not improve the model performance for July. The $\mathrm{NH}_{3}$ emissions might be underestimated with the assumption of linear correlation between $\mathrm{NH}_{3}$ volatilization and soil $\mathrm{pH}$ for acidic soil, particularly in warm seasons. Three additional cases, i.e., $40 \%$ abatement of $\mathrm{SO}_{2}, 40 \%$ abatement of $\mathrm{NO}_{x}$, and $40 \%$ abatement of both species, were applied to test the sensitivity of $\mathrm{NH}_{3}$ and inorganic aerosol concentrations to precursor emissions. Under an $\mathrm{NH}_{3}$-rich condition, estimation of $\mathrm{SO}_{2}$ emissions was detected to be more effective on simulation of secondary inorganic aerosols compared to $\mathrm{NH}_{3}$. Reduced $\mathrm{SO}_{2}$ would restrain the formation of $\left(\mathrm{NH}_{4}\right)_{2} \mathrm{SO}_{4}$ and thereby enhance the $\mathrm{NH}_{3}$ concentrations. To improve the air quality more effectively and efficiently, $\mathrm{NH}_{3}$ emissions should be substantially controlled along with $\mathrm{SO}_{2}$ and $\mathrm{NO}_{x}$ in the future. 


\section{Introduction}

As the most important alkaline composition in the atmosphere, ammonia $\left(\mathrm{NH}_{3}\right)$ exerts crucial influences on atmospheric chemistry and the nitrogen cycle. $\mathrm{NH}_{3}$ participates in chemical reactions with sulfuric acid $\left(\mathrm{H}_{2} \mathrm{SO}_{4}\right)$ and nitric acid $\left(\mathrm{HNO}_{3}\right)$ and contributes to formation of secondary inorganic aerosols (SIAs) including sulfate $\left(\mathrm{SO}_{4}^{2-}\right)$, nitrate $\left(\mathrm{NO}_{3}^{-}\right)$, and ammonium $\left(\mathrm{NH}_{4}^{+}\right)$and thereby to the elevated concentrations of fine particulate matter (PM). In developed regions in eastern China, for example, SIA was observed to account for over $50 \%$ of $\mathrm{PM}_{2.5}$ mass concentrations (Yang et al., 2011; Zhang et al., 2012; Huang et al., 2014), and $\mathrm{NH}_{3}$ emissions were estimated to contribute $8 \%-11 \%$ of $\mathrm{PM}_{2.5}$ (Wang et al., 2011). Recent studies reported that the existence of $\mathrm{NH}_{3}$ could accelerate the heterogeneous oxidation of $\mathrm{SO}_{2}$ and thereby sulfate formation by neutralizing aerosol acidity (Wang et al., 2016; Cheng et al., 2016; Paulot et al., 2017). Deposition of gaseous $\mathrm{NH}_{3}$ and $\mathrm{NH}_{4}^{+}$aerosols results in soil acidification and water eutrophication. Reduced nitrogen $\left(\mathrm{NH}_{3}+\mathrm{NH}_{4}^{+}\right)$was monitored to contribute over $70 \%$ of total nitrogen deposition in China, revealing the importance of $\mathrm{NH}_{3}$ in the ecosystem (Pan et al., 2012). Recently $\mathrm{SO}_{2}$ and $\mathrm{NO}_{x}$ emissions have gradually decreased due to implementation of air pollution control measures in China; thus $\mathrm{NH}_{3}$ emissions were found to play a greater role in secondary aerosol formation and nitrogen deposition compared to previous years (Liu et al., 2013; Fu et al., 2017; Pan et al., 2018).

Quantification of $\mathrm{NH}_{3}$ sources helps better understanding its atmospheric and ecosystem effects. In contrast to $\mathrm{SO}_{2}$ and $\mathrm{NO}_{x}$ that are largely from industrial plants, $\mathrm{NH}_{3}$ comes mainly from agricultural activities that are more difficult to track, including livestock farming and fertilizer use, and relatively large uncertainty in $\mathrm{NH}_{3}$ emission inventories exists. Given the intensive agriculture across the country, various methods were developed to estimate China's $\mathrm{NH}_{3}$ emissions at the national level for the last 20 years, but clear discrepancies exist between studies, as summarized by Zhang et al. (2018). With meteorology, soil property, the method of fertilizer application, and different processes of manure management considered in emission factor (emissions per unit level of activity) determination in particular, the national $\mathrm{NH}_{3}$ emissions estimated by the Peking University group (Huang et al., 2012; Kang et al., 2016) were 39\%$46 \%$ smaller than those by the Tsinghua University group (Dong et al., 2010; Zhao et al., 2013). Emissions of certain sectors differed significantly between various methods. For example, Zhao et al. (2013) and Kurokawa et al. (2013) calculated China's $\mathrm{NH}_{3}$ emissions from fertilizer use at 9.5$9.8 \mathrm{Tg}$, over 3 times the estimation by Kang et al. (2016). With a fertilizer modeling system that couples an air quality model and an agroecosystem model, Fu et al. (2015) made an estimate at 3.0 Tg, similar to Kang et al. (2016). Besides the annual emission level, discrepancies also exist in the interannual trend in emissions. Kang et al. (2016) estimated that the national $\mathrm{NH}_{3}$ emissions reached a peak in 1996 and declined thereafter, while Zhang et al. (2017) and Kurokawa et al. (2013) expected a continuous growth till 2008 and 2015, respectively. The growth in $\mathrm{NH}_{3}$ emissions was supported by satellite observation. Based on the measurement of Atmospheric Infrared Sounder (AIRS), for example, Warner et al. (2017) suggested an annual increasing rate of $\mathrm{NH}_{3}$ concentrations at $2.3 \%$ from 2002 to 2016 in China, and it was partly attributed to the elevated emissions from fertilizer use.

Although varied methods and data resulted in discrepancies between inventories and big uncertainty in $\mathrm{NH}_{3}$ emission estimation, very little attention has been paid to those discrepancies and the underlying reasons. At the regional scale, in particular, inclusion of high-resolution information on meteorology and land use would potentially improve the spatial and seasonal distribution of agricultural $\mathrm{NH}_{3}$ emissions in the inventory. Previous studies have demonstrated that including meteorology could improve $\mathrm{NH}_{3}$ emission estimation for both Europe and North America compared to simple static methodology (Bash et al., 2013; Gyldenkaerne et al., 2005; Skjøth et al., 2011; Wichink Kruit et al., 2012), and intercomparison studies have not been sufficiently conducted for China. Moreover, few studies were conducted to evaluate $\mathrm{NH}_{3}$ emission inventories incorporating air quality models and available ground and satellite observations. One possible reason is the lack of sufficient ground observation data on $\mathrm{NH}_{3}$ and $\mathrm{NH}_{4}^{+}$aerosols open to the public, as they are currently not regulated air pollutants in China and thus not regularly monitored by the government. In addition, uncertainty also exists in satellite observation of $\mathrm{NH}_{3}$ columns and the retrieved data need further validation (Van Damme et al., 2015). Without comparison of different inventories in detail and appropriate assessment based on model performance, the limitations of current emission estimates and the future steps for inventory improvement remain unclear.

In this study, therefore, we chose the Yangtze River Delta (YRD) region to develop and evaluate the emission inventories of $\mathrm{NH}_{3}$ with different methods and data sources. Located in eastern China, the YRD region contains the city of Shanghai and the provinces of Jiangsu, Zhejiang, and Anhui (see Fig. 1 for its location and prefectural cities) and is one of China's most developed and heavily polluted regions (Xiao et al., 2011; Cheng et al., 2014; Guo et al., 2017). It is an important area of agriculture production and was identified as an " $\mathrm{NH}_{3}$-rich" region regarding SIA formation (Wang et al., 2011). We developed two $\mathrm{NH}_{3}$ emission inventories for 2014 based on constant emission factors (E1) and those characterizing agricultural processes (E2). The two inventories were compared to each other to reveal the differences in spatial and seasonal patterns of $\mathrm{NH}_{3}$ emissions and their origins. Evaluation of the two inventories was further conducted using the Models-3/Community Multiscale Air Quality (CMAQ) system and available observations from ground stations and satellites. Environmental parameters that might influence $\mathrm{NH}_{3}$ simulation were identified through the model 
performance. Finally, the effects of $\mathrm{SO}_{2}$ and $\mathrm{NO}_{x}$ emission estimates on $\mathrm{NH}_{3}$ and $\mathrm{NH}_{4}^{+}$aerosol simulation were evaluated through sensitivity analysis, and the policy implications of air quality improvement are accordingly detailed.

\section{Data and methods}

\subsection{Emission inventory based on constant emission factors (E1)}

The annual $\mathrm{NH}_{3}$ emissions of the YRD region for 2014 were estimated with a bottom-up method based on the constant emission factors and then allocated to the monthly level based on the previously investigated temporal profile of emissions. The inventory contained eight source categories, i.e., fertilizer application, livestock-poultry breeding, fuel combustion, biomass burning, transportation, sewage-waste treatment, industrial processes, and human metabolization (see Table 1 for the details). Note that the emissions from pets were not included in the current work, due to lack of detailed information. Given their relatively small fraction in total emissions, e.g., less than $2 \%$ in the United Kingdom (Sutton et al., 1995, 2000), we believe that the uncertainty was limited. The annual emissions were calculated by prefectural city with Eq. (1):

$E_{i}=\sum_{j}\left(\mathrm{AL}_{i, j} \times \mathrm{EF}_{j} \times 10^{-3}\right)$,

where $E$ is the emissions (metric tons, t); $i$ and $j$ indicate the prefectural city and source type, respectively; $\mathrm{AL}$ is the activity level, which indicates the amount of livestock, the amount of used fertilizer, the fuel burned, or the industrial production, depending on the source type; and EF is the annual emission factor $\left(\mathrm{kg}-\mathrm{NH}_{3}\right.$ per unit of $\left.\mathrm{AL}\right)$.

The activity data were mainly taken or estimated from official statistics at the prefectural city level (if available) or provincial level. For livestock-poultry breeding, the year-end stock and slaughter numbers were used for animals with a breeding cycle respectively more and less than 1 year. If the city-level stock was unavailable, the output of livestock products by prefectural city was applied as the scaling factor to calculate the number from the provincial data. Table S1 in the Supplement summarizes the annual numbers of livestock and poultry by prefectural city in the YRD. The amount of fertilizer used by prefectural city and type was calculated as the product of sown area of cropland and fertilizer rate per unit area of cropland. The sown area by crop type was taken from city-level statistics, and the application rate by fertilizer type was obtained at the provincial level from a national investigation by NDRC (2015). The detailed results of fertilizer activity data are summarized in Table S2. As can also be seen in the table, the aggregated amount of fertilizer used by province was close to the provincial-level statistics, and the deviation relevant to the official statistics was $2.3 \%$ for the

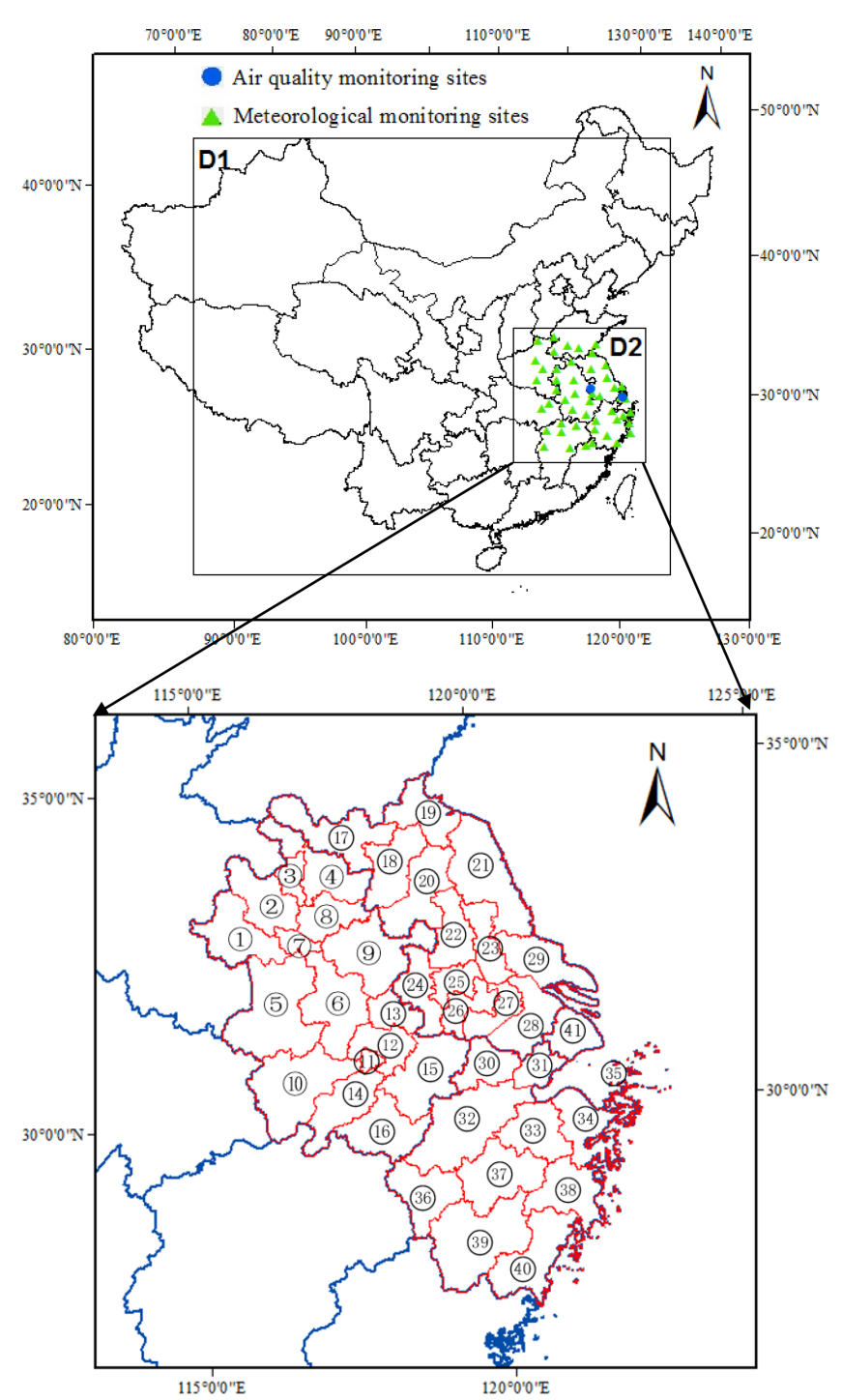

Figure 1. Research domain. The blue dots and red triangles indicate the locations of 43 meteorological monitoring sites and 2 air quality monitoring sites, respectively, and the numbers $1-41$ represent the prefectural cities of Fuyang, Bozhou, Huaibei, Suzhou, Lu'an, Hefei, Huainan, Bengbu, Chuzhou, Anqing, Tongling, Wuhu, Ma'anshan, Chizhou, Xuancheng, Huangshan, Xuzhou, Suqian, Lianyungang, Huai'an, Yancheng, Yangzhou, Taizhou, Nanjing, Zhenjiang, Changzhou, Wuxi, Suzhou, Nantong, Huzhou, Jiaxing, Hangzhou, Shaoxing, Ningbo, Zhoushan, Quzhou, Jinhua, Taizhou, Lishui, Wenzhou, and Shanghai. The map data provided by Resource and Environment Data Cloud Platform are freely available for academic use (http://www.resdc.cn/data.aspx?DATAID= 201, last access: 4 April 2020), (C) Institute of Geographic Sciences \& Natural Resources Research, Chinese Academy of Sciences. 
Table 1. Anthropogenic $\mathrm{NH}_{3}$ emission source categories.

\begin{tabular}{|c|c|c|c|}
\hline Category & Subcategory & Category & Subcategory \\
\hline Fertilizer application & $\begin{array}{l}\text { urea } \\
\text { ammonium bicarbonate } \\
\text { ammonium nitrate } \\
\text { ammonium sulfate } \\
\text { compound fertilizer }\end{array}$ & Fuel combustion & $\begin{array}{l}\text { industrial coal combustion } \\
\text { industrial oil combustion } \\
\text { industrial gas combustion } \\
\text { domestic coal combustion } \\
\text { domestic oil combustion } \\
\text { domestic gas combustion }\end{array}$ \\
\hline \multirow[t]{3}{*}{ Livestock Farming } & $\begin{array}{l}\text { beef cattle } \\
\text { dairy cow } \\
\text { horse/donkey/mule } \\
\text { sow }\end{array}$ & Biomass burning & $\begin{array}{l}\text { straw burning } \\
\text { domestic firewood } \\
\text { open }\end{array}$ \\
\hline & $\begin{array}{l}\text { hog } \\
\text { goat } \\
\text { sheep } \\
\text { layer } \\
\text { laying duck } \\
\text { broiler }\end{array}$ & Transportation & $\begin{array}{l}\text { light-duty gasoline vehicle } \\
\text { heavy-duty gasoline vehicle } \\
\text { light-duty diesel vehicle } \\
\text { heavy-duty diesel vehicle } \\
\text { motorcycle }\end{array}$ \\
\hline & $\begin{array}{l}\text { duck } \\
\text { goose } \\
\text { rabbit } \\
\text { cattle/buffalo }\end{array}$ & Sewage and waste treatment & $\begin{array}{l}\text { waste landfill } \\
\text { waste incineration } \\
\text { waste compost } \\
\text { sewage treatment }\end{array}$ \\
\hline Human being & $\begin{array}{l}\text { human sweat } \\
\text { human breath } \\
\text { human excretion } \\
\text { baby excretion }\end{array}$ & Industry sources & $\begin{array}{l}\text { ammonium synthesis } \\
\text { nitrogenous fertilizer } \\
\text { phosphate fertilizer } \\
\text { coking }\end{array}$ \\
\hline
\end{tabular}

whole YRD. The methods and data sources for activity levels of other source categories were provided in our previous studies (Zhou et al., 2017; Zhao et al., 2017; Yang and Zhao, 2019).

The annual $\mathrm{NH}_{3}$ emission factors were obtained based on a thorough literature review and summarized by source category in Table S3. The results from domestic field measurements were preferentially selected. For sources without suitable domestic measurements, the emission factors were also obtained from previous inventories that shared a similar study period as this work. The values from the US and Europe, e.g., AP-42 database (USEPA, 2002) and the EMEP/EEA guidebook (EEA, 2013a, b), were adopted when the above information was lacking.

The monthly distribution of emissions by source was taken from domestic investigations in the YRD (Li, 2012; Zhao et al., 2015; Zhou et al., 2017). For the purpose of air quality modeling, the emissions by sector were allocated into a grid system with a horizontal resolution at $9 \mathrm{~km} \times 9 \mathrm{~km}$ based on selected proxies. Those proxies included the distribution of land use (for fertilization), density of total population (for human metabolization and sewage-waste treatment) and rural population (for livestock-poultry breeding and residential solid fuel burning), gross domestic product (for industrial fuel combustion and processes), road network (for transportation), and satellite-derived fire points from the Moderate Resolution Imaging Spectroradiometer (MODIS, for open biomass burning; Davies et al., 2009).

\subsection{The method characterizing agricultural processes (E2)}

The livestock-poultry breeding emissions were recalculated integrating the detailed regional information of soil, meteorology, and agricultural processes. The same annual activity data as E1 (e.g., livestock-poultry numbers in Table S1 and fertilizer use in Table S2) were applied.

\subsubsection{Fertilizer use}

The growing seasons of crops affect the temporal distribution of fertilizer use and thereby that of $\mathrm{NH}_{3}$ emissions. We investigated the growing and farming cycles by crop type in the YRD from the regional farming database by the Ministry of Agriculture (MOA, http://202.127.42.157/moazzys/ nongshi.aspx, last access: 31 July 2019) and other publications (Zhang et al., 2009). Taking early-season rice as an example, the basal dressing was usually conducted in midApril, with all the complex fertilizer and half of the other nitrogen fertilizer used. The top dressing was conducted three times, i.e., $10 \%$ and $10 \%$ of nitrogen fertilizer used $7 \mathrm{~d}$ 
and $14 \mathrm{~d}$ after transplanting, and the $30 \%$ used for sprouting. With that information incorporated, we estimated the monthly amount of fertilizer usage by prefectural city and fertilizer type based on the annual amount in Table S2.

Emission factors of fertilization were expected to be influenced by soil acidity, temperature, and the fertilization rate. We assumed a linear correlation between the soil $\mathrm{pH}$ and $\mathrm{NH}_{3}$ volatilization rate (Huang et al., 2012), and we calculated the monthly emission factors of two fertilization types (basal dressing and top dressing) with Eqs. (2) and (3):

$$
\begin{aligned}
\mathrm{EF}_{\text {basal }} & =\left[\left(a_{\mathrm{pH}} \times \mathrm{pH}+b_{\mathrm{pH}}\right)+\left(T_{\text {basal }}-T_{0}\right) \times k_{T}\right], \\
& \times \mathrm{CF}_{\text {rate }} \times \mathrm{CF}_{\text {method }} \\
\mathrm{EF}_{\text {top }}= & {\left[\left(a_{\mathrm{pH}} \times \mathrm{pH}+b_{\mathrm{pH}}\right)+\left(T_{\text {top }}-T_{0}\right) \times k_{T}\right] \times \mathrm{CF}_{\text {rate }}, }
\end{aligned}
$$

where $\mathrm{EF}_{\text {basal }}$ and $\mathrm{EF}_{\text {top }}$ are the emission factors for basal dressing and top dressing, respectively; $a_{\mathrm{pH}}$ and $b_{\mathrm{pH}}$ are the slope and intercept depending on soil $\mathrm{pH} ; T_{0}$ and $k_{T}$ are the reference temperature and the slope depending on temperature, respectively; $T_{\text {basal }}$ and $T_{\text {top }}$ are the monthly average temperature of basal dressing and top dressing, respectively; and $\mathrm{CF}_{\text {rate }}$ and $\mathrm{CF}_{\text {method }}$ are the correction factors for fertilization rate and application method (basal dressing), respectively.

The spatial distribution of soil $\mathrm{pH}$ at a horizontal resolution of $1 \mathrm{~km} \times 1 \mathrm{~km}$ was obtained from a world soil database by the International Institute for Applied Systems Analysis (IIASA, http://webarchive.iiasa.ac.at/Research/ LUC/External-World-soil-database/HTML/, last access: 4 April 2020). The correlation data between temperature and $\mathrm{NH}_{3}$ volatilization rate were obtained from EEA (2009). $T_{\text {basal }}$ and $T_{\text {top }}$ were determined combining the information of farming season by MOA and the daily temperature data from the European Centre for Medium-Range Weather Forecasts (ECMWF, http://apps.ecmwf.int/datasets/data/ interim-full-daily/levtype=sfc/\#userconsent\#, last access: 4 April 2020). All the relevant data for emission factor correction were summarized in Table S4. The monthly $\mathrm{NH}_{3}$ volatilization rates of urea and ammonium bicarbonate (ABC), the two most applied types of fertilizer over the YRD region, are illustrated by season in Fig. S1 in the Supplement. Larger volatilization rates were found in the northern YRD for both fertilizer types, consistent with the distribution of soil $\mathrm{pH}$ across the region. Taking urea as an example, the volatilization rates in April and October were commonly smaller than the uniform value applied in E1 at $17.4 \%$, while those in July were larger. This discrepancy came partly from the consideration of fertilization types in E2. In April and October, basal dressing fertilization was commonly applied at the soil depth of $15-20 \mathrm{~cm}$, restraining the $\mathrm{NH}_{3}$ volatilization. In contrast, the relatively high temperature and top dressing fertilization conducted in July elevated the $\mathrm{NH}_{3}$ volatilization. It should be noted that the local fertilizer application introduced some bias to the soil $\mathrm{pH}$ from the global database by IIASA. Basal dressing would increase the soil $\mathrm{pH}$ (particularly for acidic soils) as indicated in a previous domestic study (Zhong et al., 2006). Due to a lack of the quantitative relation between the fertilizer application and soil $\mathrm{pH}$ at the regional scale in China, we ignored the interaction between them in Eq. (2).

Through the methodology mentioned above, the gridded emission factors and monthly activity levels were obtained to improve the spatial and temporal distributions of $\mathrm{NH}_{3}$ emissions from fertilization. Figure 2 compares the spatial distribution of the monthly fertilizer usage between E1 and E2, indicated by the relative deviation (RD):

$\mathrm{RD}=\left(\mathrm{E}_{1}-\mathrm{E}_{2}\right) /\left(\mathrm{E}_{1}+\mathrm{E}_{2}\right) / 2$.

In January and July, top dressing fertilization was conducted with limited crop types like rapeseed, corn, and paddy rice, while considerable basal dressing fertilization was investigated in April and October. Inclusion of those details in E2 resulted in smaller estimates of fertilizer use in winter and summer but larger estimates in spring and autumn compared to $\mathrm{E} 1$.

\subsubsection{Livestock-poultry breeding}

In contrast to $\mathrm{E} 1$ that calculated the $\mathrm{NH}_{3}$ emissions based on livestock numbers and annual EFs, a mass-flow approach was applied in E2 considering the nitrogen transformation at different stages of manure management (Beusen et al., 2008; EEA, 2013a; Huang et al., 2012). Commonly applied at the global or national scale, the approach calculated $\mathrm{NH}_{3}$ emissions of manure management processes from a pool of total ammoniacal nitrogen (TAN) for three main raising systems, as shown in Fig. S2. In the YRD region, only intensive and free-range systems were considered, and the TAN was calculated by livestock-poultry type based on the breeding duration, the amount and nitrogen contents of urine and feces, and the mass fraction of TAN. The parameters were taken from Yang (2008) and Huang et al. (2012), as summarized in Table S5. According to the nitrogen flow and phase of manure management, the activity levels were then classified into seven categories, including outdoor, housing solid, housing liquid, storage solid, storage liquid, spreading solid, and spreading liquid. $\mathrm{NH}_{3}$ emissions from livestock are calculated as the product of TAN of each category and the corresponding emission factors. As provided in Table S6, the temperature-dependant emission factors by stage and phase were taken from Huang et al. (2012), and the gridded emission factors can then be derived over the YRD region combining the meteorology data from ECMWF.

\subsection{Configuration of air quality modeling}

The Models-3/Community Multiscale Air Quality (CMAQ) model system version 4.7.1 was applied to evaluate the $\mathrm{NH}_{3}$ emission inventories for the YRD. CMAQ is a threedimensional Eulerian model designed for understanding the 


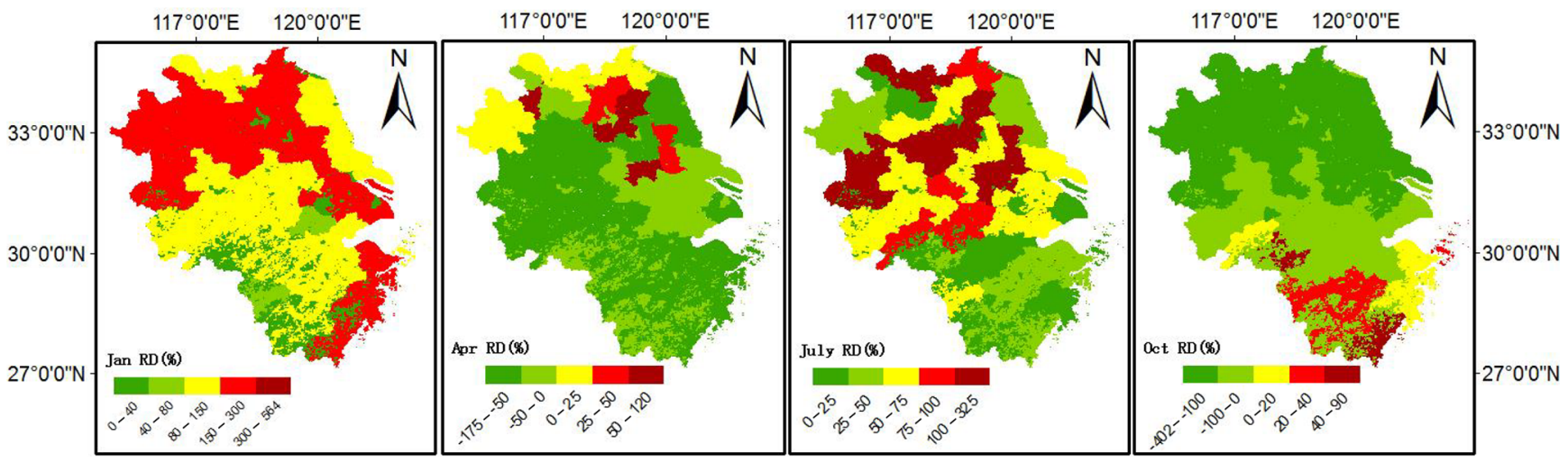

Figure 2. Differences of fertilizer application between the two inventories in $\mathrm{YRD}\left(\mathrm{RD}=\left(\mathrm{E}_{1}-\mathrm{E}_{2}\right) /\left(\mathrm{E}_{1}+\mathrm{E}_{2}\right) / 2\right)$.

complex interactions of atmospheric chemistry and physics (UNC, 2010). The model has been widely applied and tested in China (Qin et al., 2015; Zhou et al., 2017; Zheng et al., 2019). As shown in Fig. 1, two nested domains were applied with the spatial resolutions of 27 and $9 \mathrm{~km}$, on a Lambert conformal conic projection centered at $\left(34^{\circ} \mathrm{N}, 110^{\circ} \mathrm{E}\right)$. The mother domain $(\mathrm{D} 1,177 \times 127$ cells) covered most parts of China, and the second domain (D2, $118 \times 121$ cells) covered the whole YRD region. The two inventories of YRD $\mathrm{NH}_{3}$ emissions developed in this work were applied in D2. Emissions from other pollutants of anthropogenic origin in D1 and D2 outside Jiangsu were obtained from the Multiresolution Emission Inventory for China (MEIC, http://www. meicmodel.org/, last access: 4 April 2020) with an original spatial resolution of $0.25^{\circ} \times 0.25^{\circ}$. Population density was applied to relocate MEIC to each modeling domain. A high-resolution inventory that incorporates more information of local emission sources was applied for Jiangsu (JS; Zhou et al., 2017). Both MEIC and JS inventories are for 2012. The emissions for 2014 were obtained using a simple scaling method based mainly on changes in activity levels (e.g., energy consumption and industrial production) between the 3 years. The biogenic emission inventory was from the Model of Emissions of Gases and Aerosols from Nature 2.1 (MEGAN2.1; Guenther et al., 2012; Sindelarova et al., 2014), and the emission inventories of $\mathrm{Cl}, \mathrm{HCl}$, and lightning $\mathrm{NO}_{x}$ were from the Global Emissions Initiative (GEIA; Price et al., 1997). Meteorological fields were provided by the Weather Research and Forecasting Model (WRF) version 3.4, a state-of-the-art atmospheric modeling system designed for both meteorological research and numerical weather prediction (Skamarock et al., 2008), and the gas-phase Carbon Bond (CB05) mechanism and AERO5 aerosol module were adopted. Other details on model configuration and parameters were given in Zhou et al. (2017). The simulations were conducted for January, April, July, and October to represent the four typical seasons in 2014. A $5 \mathrm{~d}$ spin-up period of each month was used to minimize the influences of initial conditions in the simulations.
Using the observation data of the US National Climate Data Center (NCDC) at 43 stations in the YRD (see Fig. 1 for the locations of the stations), the WRF modeling performance was evaluated with statistical indicators including averages of simulations and observations, bias, normalized mean bias (NMB), normalized mean error (NME), rootmean-squared error (RMSE), and index of agreement (IOA). As can be found in Table S7, discrepancies between simulation and observation met the criteria by Emery et al. (2001) for most cases, implying the reliability of meteorological simulation. However, bigger errors were found for the simulation of wind direction.

\subsection{Ground-based and satellite observations}

There were very limited continuous ground measurement data available for ambient $\mathrm{NH}_{3}$ and $\mathrm{NH}_{4}^{+}$aerosol in the YRD region in 2014, particularly at rural-remote sites that are more representative for the regional atmospheric environment. We conducted online hourly measurements using MARGA (Monitor for AeRosols and Gases in ambient Air, ADI2080) at an urban site in the western downtown of Nanjing $\left(32.03^{\circ} \mathrm{N}, 118.44^{\circ} \mathrm{E}\right)$ from August 2014. MARGA is a state-of-the-art instrument which monitors near-real-time water-soluble ions in aerosols and their gaseous precursors (Lanciki, 2018), and it was able to capture rapid compositional changes in $\mathrm{PM}_{2.5}$ (Chen et al., 2017). The site was on the roof of the building of the Jiangsu Provincial Academy of Environmental Science ( $30 \mathrm{~m}$ above the ground) surrounded by residential and commercial buildings and heavy traffic (JSPAES; Li et al., 2015; Chen et al., 2019). The data of October 2014 were applied in this work to evaluate the $\mathrm{NH}_{3}$ inventories through air quality simulation. In addition, the hourly data of online measurement with MARGA were available at a suburban site in Pudong, Shanghai (SHPD), for April, July, and October 2014 (unpublished data from Shanghai Environmental Monitoring Center).

Regarding satellite observation, the daily $\mathrm{NH}_{3}$ vertical column densities (VCDs) measured through the In- 


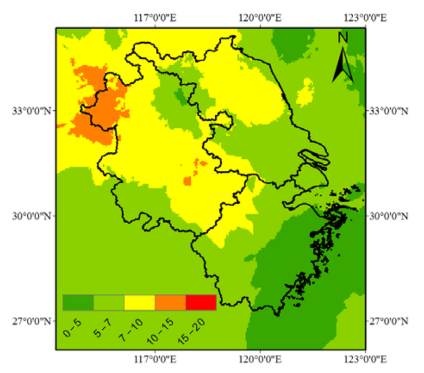

(a) January

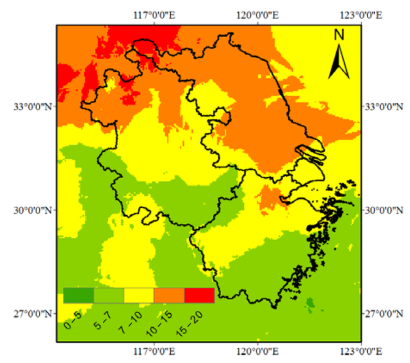

(c) July

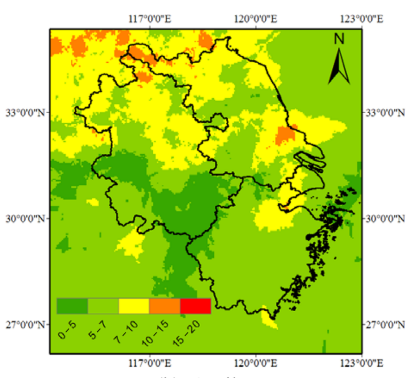

(b) April

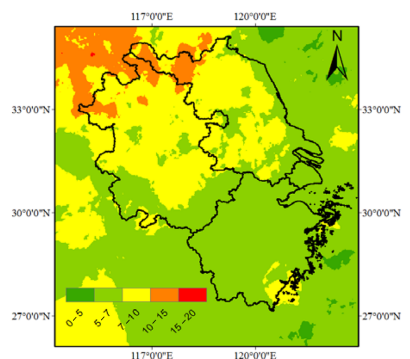

(d) October
Figure 3. The spatial distribution of monthly average of $\mathrm{NH}_{3}$ vertical columns over the YRD region from IASI satellite observation $\left(10^{15}\right.$ molec. $\left.\mathrm{cm}^{-2}\right)$.

frared Atmospheric Sounding Interferometer (IASI) were downloaded from the ESPRI data center (http://cds-espri. ipsl.upmc.fr/etherTypo/index.php?id=1700\&L=1, last access: 4 April 2020). We used the data in the domain (26.1$35.4^{\circ} \mathrm{N}, 114.2-124.1^{\circ} \mathrm{E}$ ) with a 9:30 local time Equator crossing time to evaluate the $\mathrm{NH}_{3}$ emissions. Only pixels with radiative cloud fraction $<25 \%$, relative error $<100 \%$, and absolute error $<5 \times 10^{15}$ molec. $\mathrm{cm}^{-2}$ were used following the criteria of previous studies (Van Damme et al., 2014, 2015). The monthly average VCDs for January, April, July, and October 2014 were calculated and allocated into a grid system of $0.5^{\circ}$ (longitude) $\times 0.25^{\circ}$ (latitude) using the Kriging interpolation method, as shown in Fig. 3.

\section{Results and discussions}

\subsection{Comparison between the two inventories}

Table 2 summarizes the $\mathrm{NH}_{3}$ emissions estimated with E1 and E2 by source category and province for the YRD region in 2014. Agricultural activities (livestock farming and fertilizer) were identified as the most important sources of $\mathrm{NH}_{3}$, with the fraction of total emissions ranging from $74 \%$ to $84 \%$ in the two methods. Applying the constant emission factors, E1 derived a total $\mathrm{NH}_{3}$ emission estimate $60 \%$ larger than that by $\mathrm{E} 2$ that characterized the agricultural processes. In particular, emissions from agricultural activities in E1 were calculated as twice those in E2. At the national scale, similarly, Dong et al. (2010) applied the constant emission factors and estimated the total $\mathrm{NH}_{3}$ emissions to be $16.1 \mathrm{Tg}$

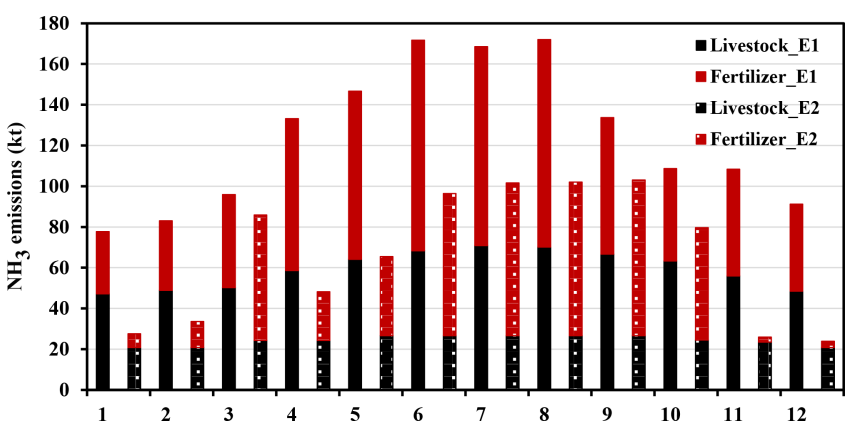

Figure 4. Monthly $\mathrm{NH}_{3}$ emissions from fertilizer use and livestock farming in E1 and E2.

for China, $64 \%$ larger than $9.8 \mathrm{Tg}$ by Huang et al. (2012) with the agricultural processes characterized. The clearly larger estimation by constant emission factors was due partly to the fact that most domestic measurements on the emission factors of $\mathrm{NH}_{3}$ from fertilizer application were conducted in hot seasons (late spring and summer), when the basal dressing of single-season rice and maize and top dressing of wheat were usually conducted (Cai et al., 2002; Huo et al., 2015; $\mathrm{Su}$ et al., 2006). However, the crop rotation varied a lot in China, and part of the nitrogen fertilizer was actually not applied in hot seasons. Emission estimation based on those emission factors may thus overestimate the $\mathrm{NH}_{3}$ emission intensity (Huo et al., 2015; Wang et al., 2011; Zhang et al., 2010). Among the provinces, the fraction from Jiangsu of YRD emissions ranged from $45 \%$ to $47 \%$ in the two methods, followed by Anhui with around $37 \%$. Agricultural activities were relatively intensive in the two provinces: Jiangsu and Anhui contributed $46 \%$ and $33 \%$ of the economic output of agriculture and livestock-poultry farming in the YRD, and the collective fraction of fertilizer use by the two provinces reached $84 \%$. In contrast, agricultural activities were limited in Shanghai and Zhejiang, with smaller emissions estimated in both inventories.

The monthly distribution of $\mathrm{NH}_{3}$ emissions in the two inventories is illustrated in Fig. 4. Both inventories indicated relatively large emissions in summer (from June to August), and elevated emissions were also found in March and September in E2. The difference comes mainly from the effect of farming season on fertilization process. For example, the top dressing fertilization for winter wheat was conducted mostly during the seedling establishment and elongation stage in the following spring, resulting in enhanced use of nitrogen fertilizer in March. Moreover, September was the month with the highest temperature following summer in the YRD in 2014, and the elevated $\mathrm{NH}_{3}$ volatilization led to large emissions in E2. Compared to the fertilizer use, less variation in monthly emissions was found for livestock-poultry breeding, as very limited change in livestock amount was detected in both inventories. 
Table 2. Two anthropogenic $\mathrm{NH}_{3}$ emission inventories in the YRD region in $2014(\mathrm{Gg})$.

\begin{tabular}{|c|c|c|c|c|c|c|c|c|c|c|}
\hline & Method & Livestock & Fertilizer & $\begin{array}{r}\text { Chemical } \\
\text { industry }\end{array}$ & $\begin{array}{r}\text { Biomass } \\
\text { burning }\end{array}$ & $\begin{array}{r}\text { Waste } \\
\text { disposal }\end{array}$ & Traffic & $\begin{array}{r}\text { Fuel } \\
\text { combustion }\end{array}$ & $\begin{array}{l}\text { Human } \\
\text { beings }\end{array}$ & Total \\
\hline \multirow[t]{2}{*}{ Shanghai } & E1 & 14.9 & 11.9 & 0.1 & 0.3 & 5.0 & 1.9 & 5.1 & 5.5 & 44.5 \\
\hline & E2 & 6.5 & 9.0 & & & & & & & 33.2 \\
\hline \multirow[t]{2}{*}{ Jiangsu } & E1 & 340.8 & 357.4 & 14.1 & 29.1 & 6.0 & 8.6 & 5.2 & 30.8 & 791.9 \\
\hline & E2 & 145.6 & 257.1 & & & & & & & 496.5 \\
\hline \multirow[t]{2}{*}{ Zhejiang } & E1 & 115.7 & 93.8 & 2.4 & 10.6 & 6.9 & 7.7 & 4.7 & 28.3 & 270.1 \\
\hline & E2 & 37.4 & 49.3 & & & & & & & 147.2 \\
\hline \multirow[t]{2}{*}{ Anhui } & E1 & 241.5 & 314.9 & 14.7 & 35.9 & 2.8 & 3.3 & 7.3 & 37.7 & 658.2 \\
\hline & E2 & 102.3 & 185.9 & & & & & & & 389.9 \\
\hline \multirow[t]{2}{*}{ Total } & E1 & 712.7 & 778.0 & 31.2 & 75.9 & 20.7 & 21.6 & 22.3 & 102.2 & 1764.7 \\
\hline & E2 & 291.8 & 501.3 & & & & & & & 1067.0 \\
\hline
\end{tabular}

Illustrated in Fig. 5 are the spatial distributions of emissions from fertilizer use, livestock-poultry breeding, and all categories in the two inventories. Both inventories indicated large emission intensities in northern Jiangsu (Xuzhou and Yancheng) and northern Anhui (Fuyang, Bozhou, and Suzhou) with abundant agricultural production. Xuzhou and Yancheng collectively contributed $36 \%, 31 \%$, and $41 \%$ of the provincial fertilizer use, agricultural economic product, and livestock-poultry farming product in Jiangsu, respectively. Similarly, Fuyang, Bozhou, and Suzhou collectively contributed $36 \%, 36 \%$, and $35 \%$ of the provincial sown area, agricultural economic product, and livestock-poultry farming product in Anhui, respectively.

The differences in spatial pattern between the two inventories were further investigated for total and fertilizer use emissions by month, through the indicator RD calculated with Eq. (4). As shown in Fig. 6, larger RD was found in northern Jiangsu, northern Anhui, and eastern Zhejiang, while smaller $\mathrm{RD}$ was found in western Zhejiang. The emissions in E1 were commonly larger than those in E2 across the YRD region for January and April. In contrast, larger emissions in E2 were found in northern Jiangsu (e.g., Xuzhou and Yancheng) and northern Anhui for July and October. The discrepancy resulted from the combined effect of varied activity data and emission factors as described in Sect. 2.2: top dressing fertilization and high temperature led to enhanced volatilization rate and thereby emissions of $\mathrm{NH}_{3}$ in $\mathrm{E} 2$, and the abundant fertilizer use in the cropland in the northern YRD was the main reason for the high emissions in October.

Figure 7 compares the $\mathrm{NH}_{3}$ emissions by province and source category in this work and other available downscaled national (MEIC) or provincial inventories in the YRD region. Results from other studies commonly ranged between $\mathrm{E} 1$ and $\mathrm{E} 2$ for agriculture, the most important $\mathrm{NH}_{3}$ source. With constant emission factors applied, the MEIC estimates were similar to those in E1. Most current provincial inventories made some corrections for emissions from fertilizer use or livestock-poultry breeding, but the local geographical and meteorological information was seldom applied in the emission estimation. For example, Liu and Yao (2016) calculated the emissions from livestock-poultry breeding for Jiangsu based on TAN but did not consider the impacts of varied monthly temperatures on the emissions. Zheng et al. (2016) calculated the agricultural $\mathrm{NH}_{3}$ emissions for Anhui based on a national guideline of $\mathrm{NH}_{3}$ emission inventory development (MEP, 2014) and ignored the impact of soil condition (e.g., $\mathrm{pH}$ ) on $\mathrm{NH}_{3}$ volatilization from fertilizer use.

\subsection{Evaluation of the inventories with transport modeling and ground observations}

Figure 8 illustrates the observed and simulated hourly concentrations for gaseous $\mathrm{NH}_{3}$ and inorganic aerosol species $\left(\mathrm{NH}_{4}^{+}, \mathrm{SO}_{4}^{2-}\right.$, and $\left.\mathrm{NO}_{3}^{-}\right)$in $\mathrm{PM}_{2.5}$ for April, July, and October at SHPD and October at JSPAES. The normalized mean biases (NMBs) and normalized mean errors (NMEs) between observed and simulated concentrations and the monthly average concentrations from observation and simulation are summarized in Table 3. The simulated monthly average concentrations were close to the observed ones at both sites. The biggest discrepancy was found at SHPD for April, where the monthly average $\mathrm{NH}_{3}$ was simulated to be $56 \%$ larger than observations with E1, and the smallest was at JSPAES for October, where the simulation was $1.7 \%$ smaller than observations with $\mathrm{E} 1$. The simulated temporal variation, however, was much larger than the observed variation, leading to relatively large NME, particularly at SHPD for April. A clear difference was found for the simulation under two $\mathrm{NH}_{3}$ inventories. In general, the average of simulated $\mathrm{NH}_{3}$ concentrations at the two sites for available months was $27 \%$ smaller in E2 than that in $\mathrm{E} 1$ (note the total $\mathrm{NH}_{3}$ emissions in $\mathrm{E} 2$ were $38 \%$ smaller than those in E1 for the whole YRD region). At the SHPD site, application of E1 in CMAQ overestimated the $\mathrm{NH}_{3}$ concentration, indicated by the positive NMB values 


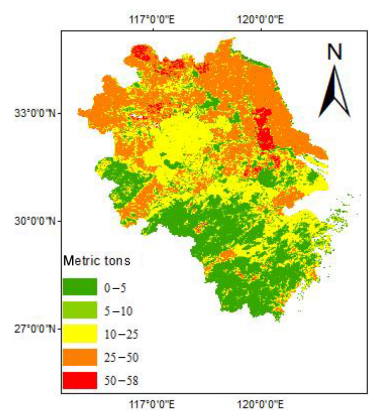

(a) Fertilizer use in E1

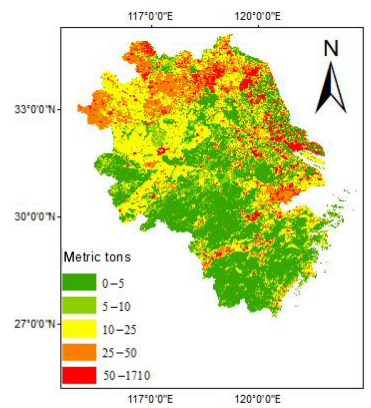

(c) Livestock farming in E1

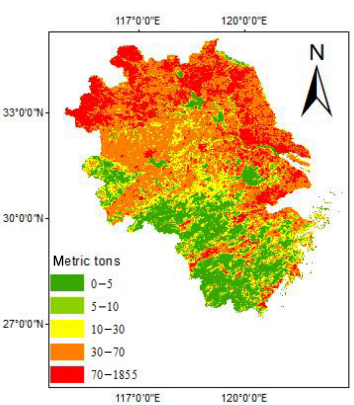

(e) Total emissions in E1

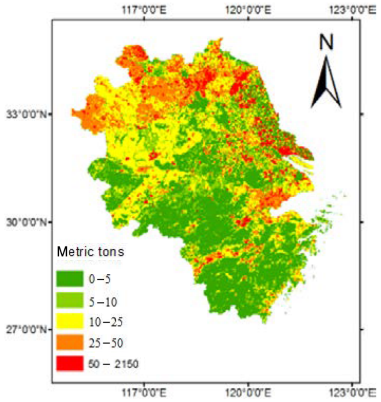

(b) Fertilizer use in E2

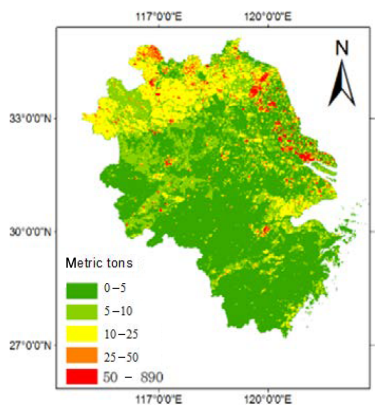

(d) Livestock farming in E2

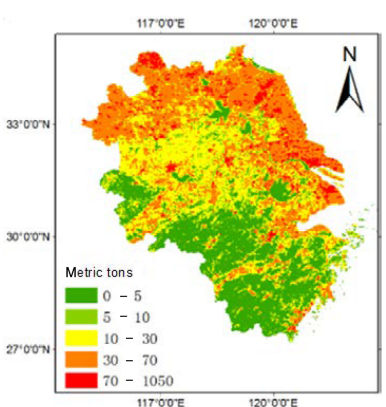

(f) Total emissions in E2

Figure 5. Spatial distribution of $\mathrm{NH}_{3}$ emissions from fertilizer use, livestock farming, and all categories in E1 and E2.

and the larger simulated concentrations than observed concentrations. Such overestimation was corrected when E2 was applied, and the NMEs with E2 were substantially reduced as well, as shown in Table 3 . The better modeling performance implies improved estimation and spatiotemporal distribution of emissions. At JSPAES, the air quality modeling with both inventories underestimated the $\mathrm{NH}_{3}$ concentrations, and the simulated monthly average concentration with E1 was much closer to observation than that with E2. The close NMEs between the two inventories indicated very limited improvement at the site, in contrast to SHPD. Located in an urban area, JSPAES might be largely affected by the local sources like transportation and residential activities. $\mathrm{NH}_{3}$ emissions of such source categories, however, were not improved in E2.

To reduce the impact of the highly uncertain hourly meteorology simulation and emission data on air quality modeling, the daily $\mathrm{NH}_{3}$ concentrations derived from simulation and

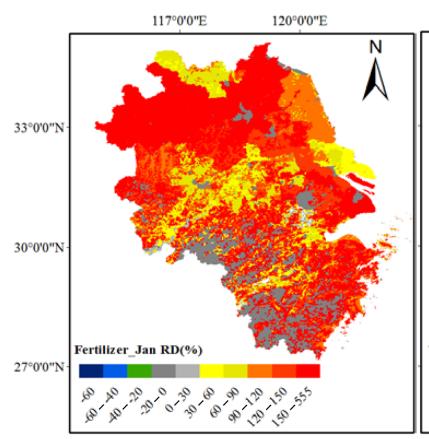

(a) Fertilizer_January

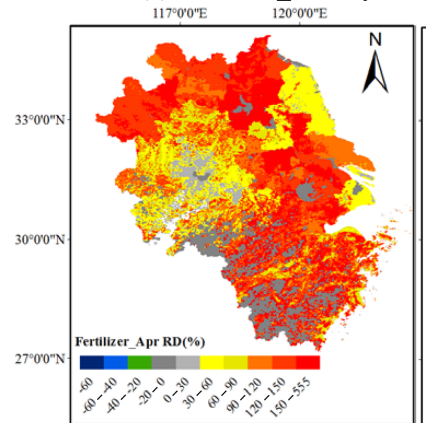

(c) Fertilizer_April

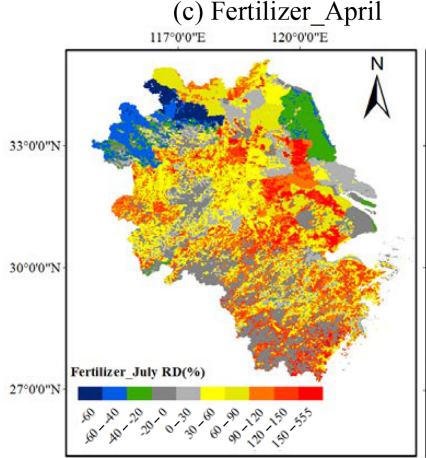

(e) Fertilizer_July

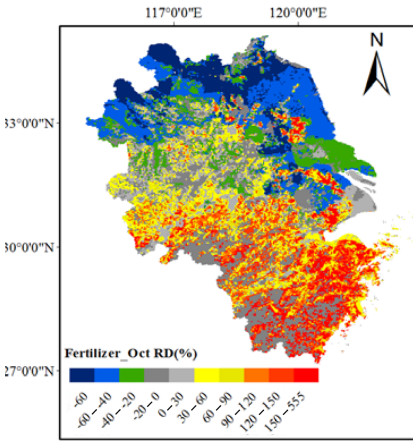

(g) Fertilizer_October

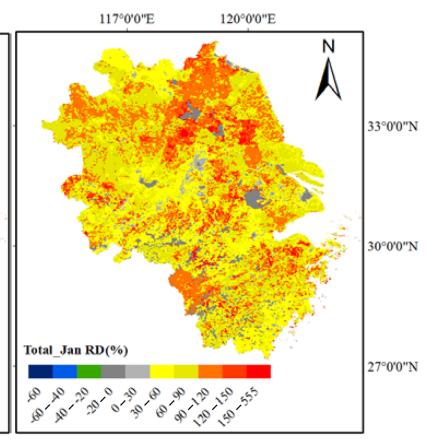

(b) Total January

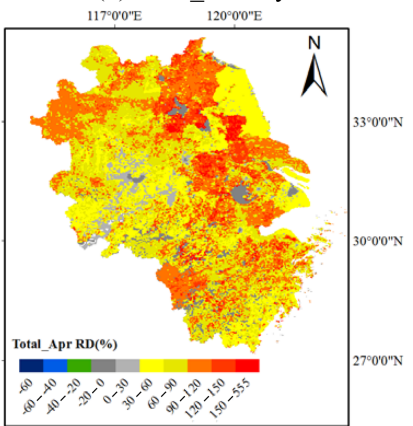

(d) Total_April

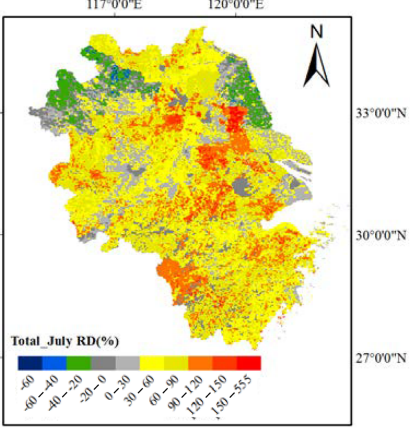

(f) Total_July

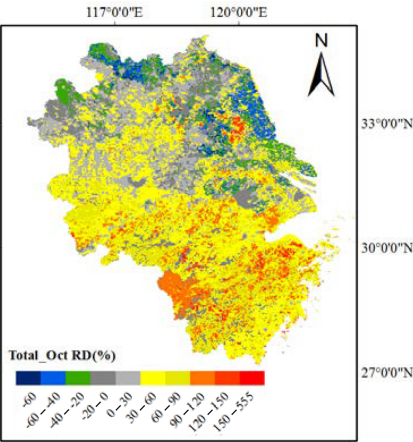

(h) Total_ October

Figure 6. Differences of $\mathrm{NH}_{3}$ emissions from fertilizer use and all categories between the two inventories $\left(\mathrm{RD}=\left(\mathrm{E}_{1}-\mathrm{E}_{2}\right) /\left(\mathrm{E}_{1}+\right.\right.$ $\left.\mathrm{E}_{2}\right) / 2$ ). 
Table 3. Model performance statistics for the hourly concentrations of $\mathrm{NH}_{3}$ and SIA from observation and CMAQ simulation with the two inventories at the SHPD and JSPAES sites for available months.

\begin{tabular}{|c|c|c|c|c|c|c|c|c|c|}
\hline & \multirow[t]{2}{*}{ Indicator } & \multicolumn{2}{|c|}{ SHPD_Apr } & \multicolumn{2}{|c|}{ SHPD_July } & \multicolumn{2}{|c|}{ SHPD_Oct } & \multicolumn{2}{|c|}{ JSPAES_Oct } \\
\hline & & E1 & E2 & E1 & E2 & E1 & E2 & E1 & E2 \\
\hline \multirow[t]{5}{*}{$\mathrm{NH}_{3}$} & NMB (\%) & 75.11 & 17.02 & 15.62 & -12.85 & 32.32 & -5.05 & 1.73 & -21.75 \\
\hline & NME (\%) & 141.08 & 103.59 & 88.72 & 78.00 & 98.36 & 76.25 & 56.94 & 53.68 \\
\hline & $r(p<0.01)$ & 0.23 & 0.23 & 0.25 & 0.23 & 0.20 & 0.18 & 0.35 & 0.33 \\
\hline & Mean sim. $\left(\mu \mathrm{g} \mathrm{m}^{-3}\right)$ & 7.12 & 4.76 & 10.70 & 8.06 & 7.39 & 5.30 & 7.75 & 5.96 \\
\hline & Mean obs. $\left(\mu \mathrm{g} \mathrm{m}^{-3}\right)$ & \multicolumn{2}{|c|}{4.58} & \multicolumn{2}{|c|}{9.25} & \multicolumn{2}{|c|}{5.58} & \multicolumn{2}{|c|}{7.62} \\
\hline \multirow[t]{5}{*}{$\mathrm{NH}_{4}^{+}$} & NMB (\%) & -8.78 & -19.14 & 12.98 & 6.11 & 84.45 & 74.02 & 15.01 & 9.53 \\
\hline & $\operatorname{NME}(\%)$ & 40.07 & 40.78 & 64.26 & 61.76 & 100.23 & 91.69 & 42.27 & 40.7 \\
\hline & $r(p<0.01)$ & 0.66 & 0.66 & 0.57 & 0.56 & 0.58 & 0.57 & 0.57 & 0.57 \\
\hline & Mean sim. $\left(\mu \mathrm{g} \mathrm{m}^{-3}\right)$ & 6.91 & 6.13 & 7.04 & 6.61 & 7.64 & 7.21 & 10.97 & 10.45 \\
\hline & Mean obs. $\left(\mu \mathrm{g} \mathrm{m}^{-3}\right)$ & \multicolumn{2}{|c|}{7.58} & \multicolumn{2}{|c|}{6.23} & \multicolumn{2}{|c|}{4.14} & \multicolumn{2}{|c|}{9.54} \\
\hline \multirow[t]{5}{*}{$\mathrm{SO}_{4}^{2-}$} & $\operatorname{NMB}(\%)$ & 24.08 & 14.05 & 50.86 & 46.84 & 91.92 & 90.41 & 14.38 & 12.53 \\
\hline & $\operatorname{NME}(\%)$ & 57.59 & 51.61 & 84.63 & 81.15 & 110.18 & 108.61 & 43.65 & 42.31 \\
\hline & $r(p<0.01)$ & 0.55 & 0.54 & 0.46 & 0.47 & 0.42 & 0.44 & 0.34 & 0.36 \\
\hline & Mean sim. $\left(\mu \mathrm{g} \mathrm{m}^{-3}\right)$ & 14.75 & 13.56 & 14.60 & 14.21 & 14.53 & 14.41 & 15.5 & 15.25 \\
\hline & Mean obs. $\left(\mu \mathrm{g} \mathrm{m}^{-3}\right)$ & \multicolumn{2}{|c|}{11.89} & \multicolumn{2}{|c|}{9.68} & \multicolumn{2}{|c|}{7.57} & \multicolumn{2}{|c|}{13.56} \\
\hline \multirow[t]{5}{*}{$\mathrm{NO}_{3}^{-}$} & NMB (\%) & -59.13 & -65.20 & -78.10 & -94.24 & 29.46 & 12.60 & -6.55 & -14.18 \\
\hline & NME (\%) & 65.72 & 70.16 & 141.43 & 142.86 & 93.69 & 70.54 & 44.81 & 44.94 \\
\hline & $r(p<0.01)$ & 0.49 & 0.50 & 0.51 & 0.52 & 0.53 & 0.49 & 0.62 & 0.61 \\
\hline & Mean sim. $\left(\mu \mathrm{g} \mathrm{m}^{-3}\right)$ & 4.93 & 4.19 & 5.39 & 4.64 & 7.32 & 6.37 & 17.53 & 16.1 \\
\hline & Mean obs. $\left(\mu \mathrm{g} \mathrm{m}^{-3}\right)$ & \multicolumn{2}{|c|}{12.05} & \multicolumn{2}{|c|}{9.01} & \multicolumn{2}{|c|}{5.65} & \multicolumn{2}{|c|}{18.76} \\
\hline
\end{tabular}

Note: obs. and sim. indicate the results from observation and simulation, respectively. The NMB and NME were calculated using the following equations ( $P$ and $O$ indicate the results from modeling prediction and observation, respectively):

$\mathrm{NMB}=\frac{\sum_{i=1}^{n}\left(P_{i}-O_{i}\right)}{\sum_{i=1}^{n} O_{i}} \times 100 \% ; \mathrm{NME}=\frac{\sum_{i=1}^{n}\left|P_{i}-O_{i}\right|}{\sum_{i=1}^{n} O_{i}} \times 100 \%$.

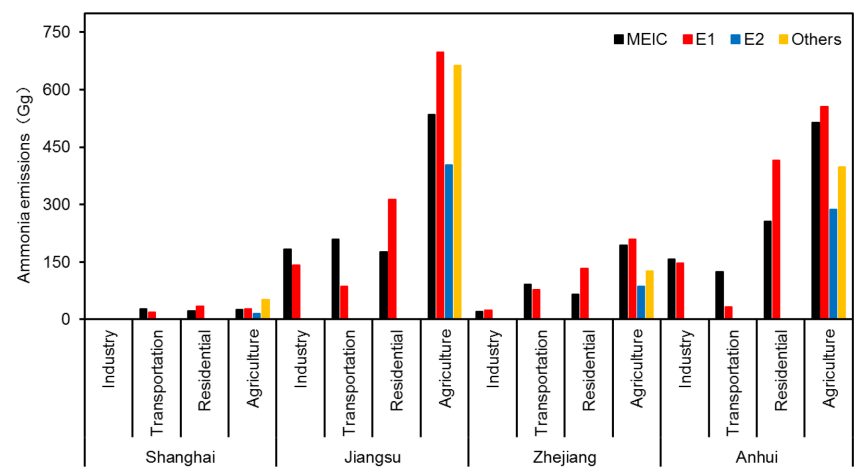

Figure 7. Comparison between the estimated $\mathrm{NH}_{3}$ emissions in this work and other studies by province and source category. "Others" indicates Fang et al. (2015), Liu and Yao (2016), Yu et al. (2016), and Zheng et al. (2016) for Shanghai, Jiangsu, Zhejiang, and Anhui, respectively. observation were further compared for October at JSPAES. As illustrated in Fig. S3, better agreement between observation and simulation was achieved for the daily concentrations than the hourly concentrations, and the NMEs for E1 and E2 were reduced from $56.9 \%$ and $53.7 \%$ to $37.0 \%$ and $32.5 \%$, respectively. Besides the emission data, uncertainty in meteorology simulation also contributed to the discrepancy between simulation and observation. For example, both inventories overestimated the concentration on 7 October but underestimated that on 21-22 October. In contrast to the southeasterly wind observed at the ground meteorology station in Nanjing, the simulated wind direction on 7 October was from the north, enhancing the $\mathrm{NH}_{3}$ transport from Yancheng and Xuzhou in northern Jiangsu with intensive agricultural activities. On 21-22 October, the underestimation of $\mathrm{NH}_{3}$ concentration resulted largely from the overestimation in wind speed by WRF.

Compared to $\mathrm{NH}_{3}$, the modeling performance for inorganic aerosols $\left(\mathrm{NH}_{4}^{+}, \mathrm{SO}_{4}^{2-}\right.$, and $\left.\mathrm{NO}_{3}^{-}\right)$is better for most cases, indicated by the smaller NMEs and larger correlation coefficients $(r)$ in Table 3. Some exceptions exist at SHPD 

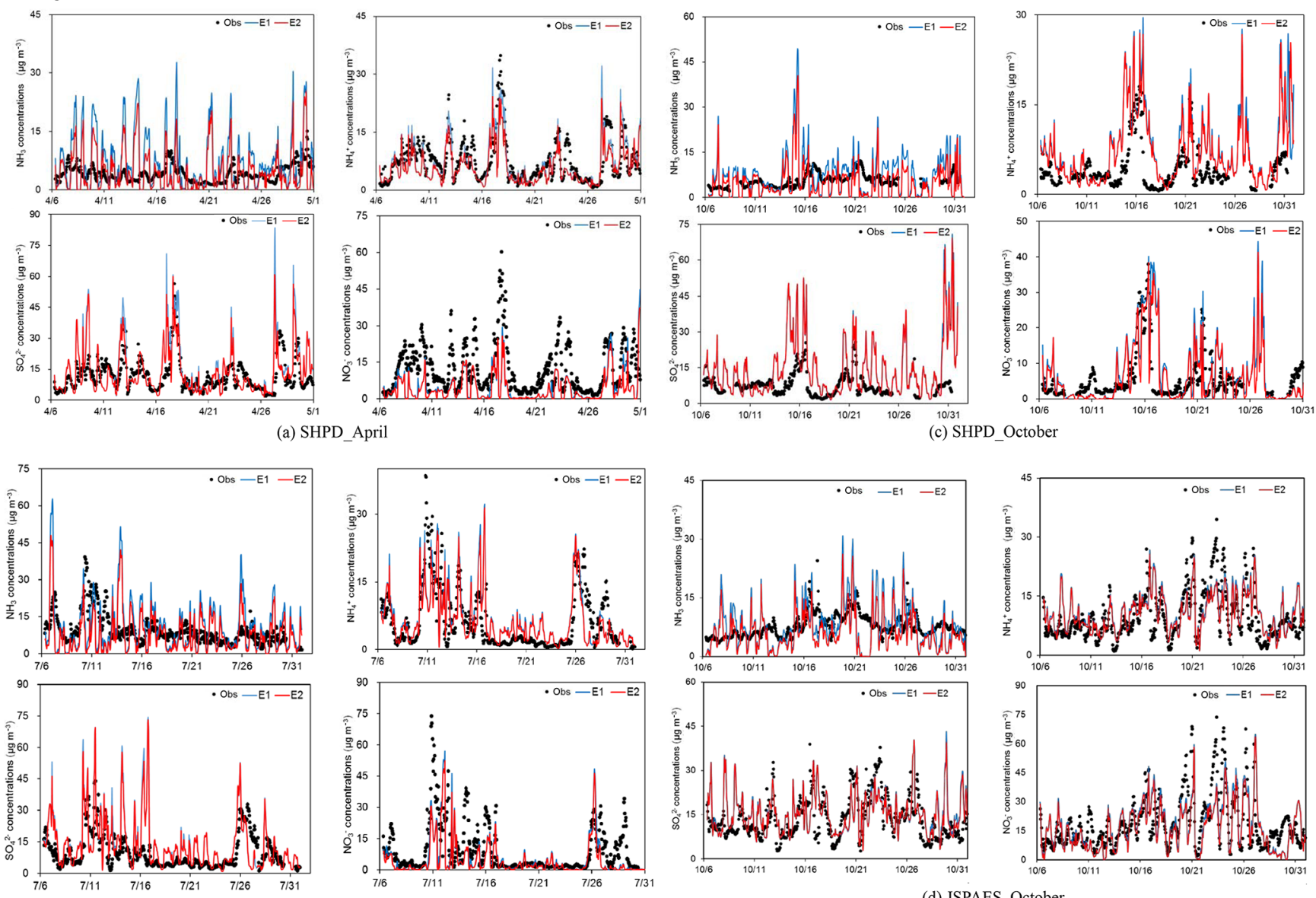

(b) SHPD July

(d) JSPAES_October

Figure 8. The observed and simulated hourly $\mathrm{NH}_{3}$ and SIA concentrations with the two inventories at the JSPAES and SHPD sites.

for $\mathrm{NH}_{4}^{+}$and $\mathrm{SO}_{4}^{2}$ in October and $\mathrm{NO}_{3}^{-}$in January. Application of $\mathrm{E} 2$ reduced the NMEs and improved the simulation of $\mathrm{NH}_{4}^{+}$and $\mathrm{SO}_{4}^{2}$ moderately, but there were no significant changes between the modeling results with $\mathrm{E} 1$ and E2. The averages of simulated concentrations at the two sites for available months were $7 \%, 3 \%$, and $12 \%$ smaller in $\mathrm{E} 2$ than those in $\mathrm{E} 1$ for $\mathrm{NH}_{4}^{+}, \mathrm{SO}_{4}^{2-}$, and $\mathrm{NO}_{3}^{-}$, respectively, and the differences were clearly smaller than for $\mathrm{NH}_{3}$ at $27 \%$. As a large fraction of inorganic aerosols come from secondary chemistry reaction, they are more representative for the regional atmosphere condition than the local environment around the measurement site. Therefore, the air quality modeling at a horizontal resolution of $9 \mathrm{~km} \times 9 \mathrm{~km}$ is expected to be able to better simulate the concentrations for SIA than the primary gaseous pollutants, particularly when emissions from some local sources are not sufficiently quantified. The simulated concentrations were commonly larger than observations for $\mathrm{NH}_{4}^{+}$and $\mathrm{SO}_{4}^{2-}$, particularly at SHPD in July and October. The uncertainty of the model could be an important source of the discrepancy, as the recent reported mechanisms of gas-to-particle conversion were not sufficiently applied in the CMAQ version we used (Wang et al., 2016; Cheng et al., 2016). In addition, positive or negative artifacts also existed in ground observations with MARGA, resulting from the unexpected reaction between acid gaseous pollutants and nitrate aerosol (Chen et al., 2017; Schaap et al., 2011; Stieger et al., 2018; Wei et al., 2015). From an emissions perspective, the overestimation was partly corrected when smaller $\mathrm{NH}_{3}$ emissions in E2 were applied instead of E1 in the model. Moreover, due to missing information on individual industrial plants, the inventory we used in CMAQ failed to fully capture the progress of emission control in the YRD region and probably overestimated the $\mathrm{SO}_{2}$ emissions (Zhang et al., 2019). The formation of sulfate ammonium aerosols could then be enhanced through the irreversible reaction between $\mathrm{SO}_{2}$ and $\mathrm{NH}_{3}$. The process simultaneously reduced the amount of $\mathrm{NH}_{3}$ reacted with $\mathrm{HNO}_{3}$, further leading to the underestimation of nitrate aerosols. As shown in Table 3, application of $\mathrm{E} 2$ with less $\mathrm{NH}_{3}$ emissions than E1 could not improve the modeling performance of nitrate aerosols. The impact of $\mathrm{SO}_{2}$ and $\mathrm{NO}_{x}$ emissions on SIA modeling will be further discussed in Sect. 3.4. 


\subsection{Evaluation of the inventories with transport modeling and satellite observations}

To be consistent with the local crossing time of IASI at 09:30 local time, the average of simulated hourly $\mathrm{NH}_{3}$ concentrations at 09:00 and 10:00 local time was applied to calculate the $\mathrm{NH}_{3} \mathrm{VCDs}$, using the following equations:

$n_{\mathrm{NH}_{3}}=\sum_{k=1}^{23} m_{k} \times \Delta H_{k} \times 100$,

$\Delta H_{k}=H \times \ln \left(\frac{p_{k}}{p_{k+1}}\right)$,

where $n_{\mathrm{NH}_{3}}$ is the $\mathrm{NH}_{3}$ VCDs from the CMAQ model (molec. $\mathrm{cm}^{-2}$ ); $m_{k}$ is the simulated $\mathrm{NH}_{3}$ concentrations at the vertical layer $k$ in the CMAQ (molec. $\mathrm{cm}^{-3}$ ); $\Delta H$ is the height of layer $k(\mathrm{~m}) ; H$ represents the height when the pressure of atmosphere declines to $1 / e$ of the original value; and $p$ is the air pressure. Figure 9 illustrates the simulated $\mathrm{NH}_{3}$ VCDs with E1 and E2 for January, April, July, and October. Similar spatial patterns are found with the two inventories; i.e., relatively large $\mathrm{NH}_{3}$ VCDs were simulated mostly in northern Jiangsu and northern Anhui Province, consistent with the hot spot of $\mathrm{NH}_{3}$ emissions. The simulated $\mathrm{NH}_{3}$ VCDs with E1 were $53 \%$ larger than those with E2 across the whole YRD region, with the maximum and minimum monthly differences calculated at $73 \%$ and $31 \%$ for April and October, respectively. The NMB, NME, and correlation coefficient $(r)$ between the observed and simulated VCDs and the monthly average VCDs from observation and simulation are summarized in Table 4. Application of both inventories resulted in larger $\mathrm{NH}_{3}$ VCDs than those from satellite observation for January and October, while the simulated VCDs for April and July were smaller. Besides the uncertainty from monthly distribution of $\mathrm{NH}_{3}$ emissions, the bias from WRF modeling on temperature might also contribute to the discrepancy between simulated and observed VCDs. As shown in Table S7, WRF overestimated the monthly temperature in January and October, with the NMBs calculated at $26.6 \%$ and $0.34 \%$, and underestimated it in April and July, with the NMBs calculated at $-1.62 \%$ and $-2.51 \%$, respectively. Compared to E1, application of E2 significantly reduced the NMEs from $83.8 \%$ to $37.5 \%$ for January and largely corrected the overestimation in VCD simulation for January and October. The simulated VCDs were $4.3 \%$ larger and $1.4 \%$ smaller than observations for the 2 months, respectively. The results implied satisfying agreement between the simulated and observed VCDs over the YRD region. Improvement in $\mathrm{NH}_{3} \mathrm{VCD}$ simulation was also found for April when E2 instead of E1 was applied in the air quality modeling, with the NME reduced from $65.8 \%$ to $60.7 \%$. For July, however, application of E2 did not improve the model performance, implying that the current method in E2 could possibly underestimate the $\mathrm{NH}_{3}$ volatilization when the actual ambient temperature was high. Besides the emissions, the discrepancy could result from various factors including the uncertainty in chemical mechanisms in CMAQ and environmental conditions. Errors from satellite retrieval could also contribute to the inconsistency between simulation and observation. In their study, van Damme et al. (2014), for example, estimated an error of $19 \%$ for the total $\mathrm{NH}_{3}$ columns in Asia. As the ESPRI product of $\mathrm{NH}_{3}$ VCDs we applied in the study does not provide the averaging kernel, however, uncertainty in $\mathrm{NH}_{3}$ column retrieval could result from the reduced sensitivity of satellite measurement towards the surface.

To further investigate the impact of soil $\mathrm{pH}$ on the emissions and thereby the modeling performance on $\mathrm{NH}_{3} \mathrm{VCDs}$, the soil in the YRD region was classified to three types, acidic soil ( $\mathrm{pH} \leq 6.5)$, neutral soil $(6.5<\mathrm{pH} \leq 7.5)$, and alkali soil $(\mathrm{pH}>7.5)$, and the NMBs and NMEs between the simulated and observed $\mathrm{NH}_{3}$ VCDs were calculated by soil type and month, as summarized in Table 5. For neutral and acidic soil, application of E2 that considers the effect of farming season, geophysical condition, and manure management on $\mathrm{NH}_{3}$ emission rates resulted in clearly smaller NMEs than E1, implying the improvement in emission estimation. For acidic soil, however, the NMBs were negative for all the months when E2 was applied, and the NMEs were elevated compared to E1 except for January. Moreover, application of E2 resulted in negative NMBs for neutral and alkali soil in April and July as well. Those results implied that E2 possibly underestimated the $\mathrm{NH}_{3}$ emissions for acidic soil in particular for warm seasons. With the correction of $\mathrm{pH}$ and temperature, the $\mathrm{NH}_{3}$ volatilization rate from basal dressing fertilization was relatively low, indicating that the current linear assumption between the soil $\mathrm{pH}$ and $\mathrm{NH}_{3}$ volatilization rate might not be appropriate for soil with low $\mathrm{pH}$ values for eastern China. As shown in Fig. S4, the measured $\mathrm{NH}_{3}$ volatilization rates from urea and $\mathrm{ABC}$ fertilizer use under relatively high soil pH (Zhang et al., 2002; Zhong et al., 2006) were close to the estimated values in E2, but the measured results for acidic soil were clearly larger than those in E2.

Limitation should be acknowledged in the emission comparison and evaluation. Besides those we paid extra attention to in E2 (e.g., temperature, soil property, fertilizer application method, and manure management process), other factors could also be influential on air-surface exchange of $\mathrm{NH}_{3}$ and thereby $\mathrm{NH}_{3}$ emissions, including meteorology parameters (wind speed, precipitation, and leaf surface wetness), surface layer turbulence, air and surface heterogeneous-phase chemistry, and plant physiological conditions (Flechard et al., 2013; Gyldenkaerne et al., 2005, Skjøth et al., 2011). With those factors integrated in a bidirectional surface-atmosphere exchange module in air quality modeling, the $\mathrm{NH}_{3}$ emission inventories were improved and the biases in simulation of $\mathrm{NH}_{3}$ and $\mathrm{NH}_{4}^{+}$aerosol concentrations were reduced for both the US and Europe (Bash et al., 2013; Wichink Kruit et al., 2012). The fact that we ignored given parameters and processes in the current work could thus partly explain the discrepancy between the simulation and observations. Applying the bidirectional $\mathrm{NH}_{3}$ exchange 


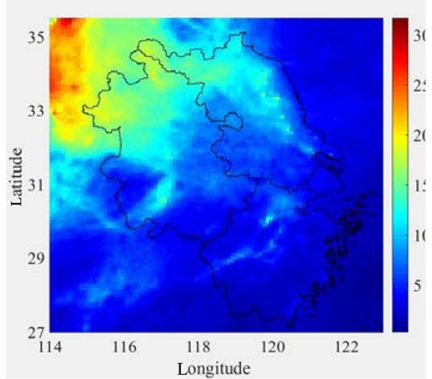

(a) E1 January

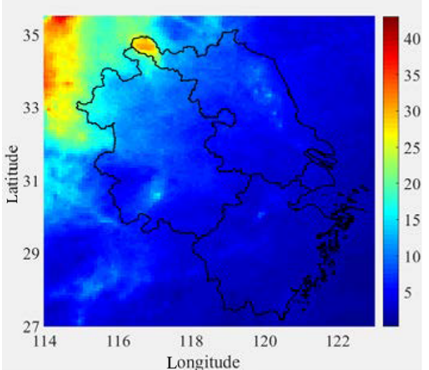

(e) E2 January

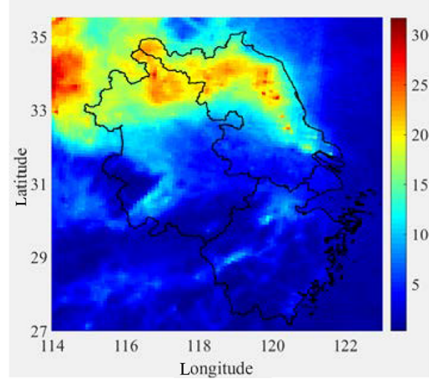

(b) E1 April

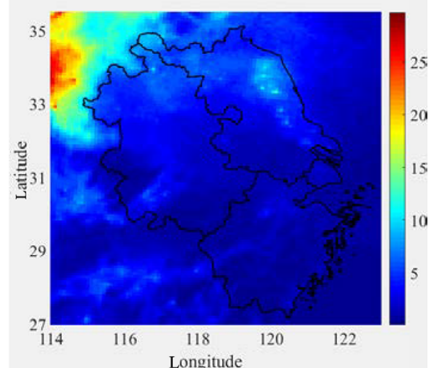

(f) E2 April

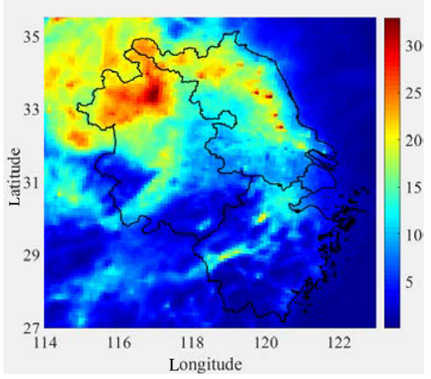

(c) E1 July

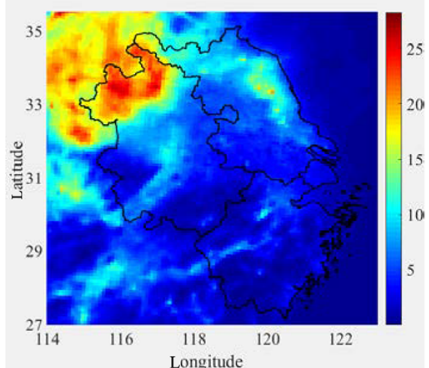

(g) E2 July

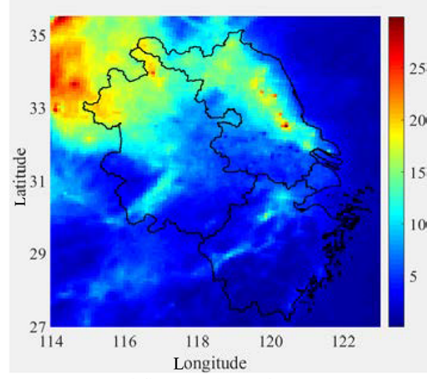

(d) E1 October

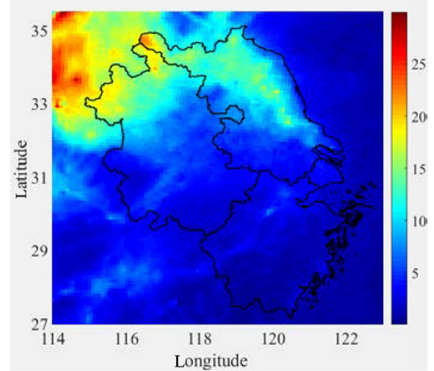

(h) E2 October

Figure 9. The $\mathrm{NH}_{3}$ VCDs in the YRD region simulated with the two inventories by month.

Table 4. Model performance statistics for the daily $\mathrm{NH}_{3}$ VCDs from IASI observation and CMAQ simulation using the two inventories by month.

\begin{tabular}{|c|c|c|c|c|c|c|c|c|}
\hline & \multicolumn{2}{|c|}{ January } & \multicolumn{2}{|c|}{ April } & \multicolumn{2}{|c|}{ July } & \multicolumn{2}{|c|}{ October } \\
\hline & E1 & E2 & E1 & E2 & E1 & E2 & E1 & E2 \\
\hline NMB (\%) & 77.02 & 4.29 & 28.49 & -59.12 & 12.19 & -34.12 & 29.46 & -1.77 \\
\hline NME (\%) & 83.83 & 37.54 & 65.8 & 60.07 & 43.93 & 51.91 & 46.38 & 43.17 \\
\hline$r(p<0.01)$ & 0.38 & 0.42 & 0.50 & 0.51 & 0.68 & 0.64 & 0.50 & 0.55 \\
\hline Mean sim. & 14.09 & 8.30 & 9.57 & 3.40 & 11.28 & 6.65 & 10.00 & 7.61 \\
\hline IASI obs. & \multicolumn{2}{|c|}{7.96} & \multicolumn{2}{|c|}{7.54} & \multicolumn{2}{|c|}{10.23} & \multicolumn{2}{|c|}{7.72} \\
\hline
\end{tabular}

module, for example, Wichink Kruit et al. (2012) found increased $\mathrm{NH}_{3}$ concentrations for agricultural source areas due to the elevated lifetime and transport distance of $\mathrm{NH}_{3}$ in the model. The result implied a possible correction on the underestimation in $\mathrm{NH}_{3}$ concentrations, as shown in Tables 3 and 4. Therefore, a more comprehensive evaluation and comparison in $\mathrm{NH}_{3}$ emissions is thus suggested for the future, including the bidirectional $\mathrm{NH}_{3}$ exchange and the top-down constraint with inverse modeling.

\subsection{Impacts of $\mathrm{SO}_{2}$ and $\mathrm{NO}_{x}$ emission estimates on simulated $\mathrm{NH}_{3}$ and aerosols}

Besides the meteorology condition, $\mathrm{NH}_{3}$ emissions, and soil $\mathrm{pH}$, the estimates of $\mathrm{SO}_{2}$ and $\mathrm{NO}_{x}$ emissions could influence the $\mathrm{NH}_{3}$ and SIA simulation as well. $\mathrm{SO}_{2}$ can be transformed to $\mathrm{S}$ (IV) through liquid-phase reaction and then be oxidized to $\mathrm{S}$ (VI) by $\mathrm{O}_{3}$, or it can be directly oxidized to $\mathrm{H}_{2} \mathrm{SO}_{4}$ by $\mathrm{H}_{2} \mathrm{O}_{2}$ or the hydroxyl radical $(\cdot \mathrm{OH}) . \mathrm{HNO}_{3}$ can be formed through $\mathrm{NO}_{2}$ oxidation by $\cdot \mathrm{OH}$ in daytime or through hydrolysis of $\mathrm{N}_{2} \mathrm{O}_{5}$ at the aerosol surface at night. Normally $\mathrm{NH}_{3}$ preferentially reacts with $\mathrm{H}_{2} \mathrm{SO}_{4}$ and relatively stable $\left(\mathrm{NH}_{4}\right)_{2} \mathrm{SO}_{4}$ is produced, while $\mathrm{NH}_{4} \mathrm{NO}_{3}$ could easily be decomposed under high-temperature or low-humidity conditions. Therefore, the ambient $\mathrm{NH}_{3}$ concentrations and formation of $\mathrm{NH}_{4}^{+}$aerosols are influenced by the balance between acidic $\left(\mathrm{SO}_{2}\right.$ and $\left.\mathrm{NO}_{x}\right)$ and alkaline component $\left(\mathrm{NH}_{3}\right)$ emissions.

As described in Sect. 2.3, the $\mathrm{SO}_{2}$ and $\mathrm{NO}_{x}$ emissions for 2014 used in this work were scaled from those for 2014 based on the changes in activity data. Ignorance of emission control progress during 2012-2014 would probably result in overestimation in emissions. The bias was evaluated through satellite observation. The daily planetary boundary layer (PBL) $\mathrm{SO}_{2}$ and tropospheric $\mathrm{NO}_{2}$ VCDs were obtained from the OMSO2 Level-3 product (http://disc.sci.gsfc. nasa.gov/Aura/data-holdings/OMI/omso2e_v003.shtml, last access: 4 April 2020) and the POMINO Level-3 product from 
Table 5. The NMBs and NMEs between the simulated and observed daily $\mathrm{NH}_{3}$ VCDs by soil $\mathrm{pH}$ and month.

\begin{tabular}{|c|c|c|c|c|c|c|c|c|c|}
\hline \multirow[t]{2}{*}{$\mathrm{pH}$} & \multirow[t]{2}{*}{ Statistics (\%) } & \multicolumn{2}{|c|}{ January } & \multicolumn{2}{|c|}{ April } & \multicolumn{2}{|c|}{ July } & \multicolumn{2}{|c|}{ October } \\
\hline & & E1 & E2 & E1 & $\mathrm{E} 2$ & E1 & E2 & E1 & E2 \\
\hline \multirow[t]{2}{*}{$\mathrm{pH}>7.5$} & NMB & 114.88 & 28.04 & 81.41 & -38.99 & 43.3 & 4.24 & 67.99 & 46.95 \\
\hline & NME & 117.8 & 49.27 & 89.23 & 44.38 & 56.11 & 48.13 & 71.49 & 57.44 \\
\hline \multirow[t]{2}{*}{$7.5<=\mathrm{pH}<6.5$} & NMB & 92.82 & 9.19 & 44.6 & -54.14 & 39.27 & -10.78 & 44.01 & 11.13 \\
\hline & NME & 95.83 & 34.16 & 64.13 & 54.7 & 52.52 & 45.54 & 52.54 & 37.69 \\
\hline \multirow[t]{2}{*}{$\mathrm{pH}<=6.5$} & NMB & 41.61 & -11.76 & 1.30 & -67.41 & -12.43 & -55.81 & 8.64 & -25.48 \\
\hline & NME & 54.72 & 36.76 & 60.16 & 68.5 & 34.78 & 56.72 & 35.27 & 43.68 \\
\hline
\end{tabular}

the Ozone Monitoring Instrument (OMI), respectively. As shown in Table S8, all the provinces in the YRD had their $\mathrm{SO}_{2}$ and $\mathrm{NO}_{2}$ VCDs substantially reduced during 2012 2014, and the VCDs declined by $48 \%$ and $31 \%$, respectively, for the whole region. From a recent unpublished emission study, however, the $\mathrm{SO}_{2}$ and $\mathrm{NO}_{x}$ emissions were estimated to decrease by only $16 \%$ and $8 \%$ in the YRD region for the 2 years (personal communication with Cheng Huang from Shanghai Research Academy of Environmental Science, 2019). It can be inferred that the overestimation of $\mathrm{SO}_{2}$ emissions might enhance their reaction with $\mathrm{NH}_{3}$ and thereby the formation of $\left(\mathrm{NH}_{4}\right)_{2} \mathrm{SO}_{4}$ in the air quality modeling. The formation of $\mathrm{NO}_{3}^{-}$, in contrast, might be suppressed accordingly.

\subsubsection{Identification of $\mathrm{NH}_{3}$-rich and $\mathrm{NH}_{3}$-poor conditions in the YRD region}

To evaluate the nonlinear relation between gaseous pollutant emissions $\left(\mathrm{SO}_{2}, \mathrm{NO}_{x}\right.$, and $\left.\mathrm{NH}_{3}\right)$ and SIA concentrations for the YRD region, we follow Ansari and Pandis (1998) and calculated the gas ratio (GR) based on the modeling results:

$\mathrm{GR}=\frac{\left(\left[\mathrm{NH}_{3}\right]+\left[\mathrm{NH}_{4}^{+}\right]\right)-2 \times\left[\mathrm{SO}_{4}^{2-}\right]}{\left[\mathrm{NO}_{3}^{-}\right]+\left[\mathrm{HNO}_{3}\right]}$,

where the species in brackets indicate the simulated ambient concentration. A negative GR indicates an $\mathrm{NH}_{3}$-poor condition, and the enhanced $\mathrm{NH}_{3}$ emissions strengthen the oxidation of $\mathrm{SO}_{2}$ and lead to increased $\mathrm{SO}_{4}^{2-}$ (Wang et al., 2011). A GR larger than 1 indicates an $\mathrm{NH}_{3}$-rich condition. Enhanced $\mathrm{NH}_{3}$ emissions have smaller effects on growth of $\mathrm{SO}_{4}^{2-}$ concentrations, and elevated $\mathrm{SO}_{2}$ emissions may accelerate the formation of $\mathrm{NO}_{3}^{-}$aerosols, as the increased $\mathrm{NH}_{4}^{+}$and $\mathrm{SO}_{4}^{2-}$ reduce the $\mathrm{NH}_{4} \mathrm{NO}_{3}$ capacity in the liquid phase. A neutral condition is judged when GR is between 0 and 1.

Figure 10 illustrates the spatial distribution of simulated GR for the YRD region by month with $\mathrm{E} 1$ and $\mathrm{E} 2 \mathrm{NH}_{3}$ inventories. Implied by the GR values larger than 1.0 for most of the areas, the YRD region was identified under the $\mathrm{NH}_{3}$ rich condition when E1 was applied, except for southwest
Zhejiang. The judgment is consistent with previous studies (Wang et al., 2011; Dong et al., 2014). With the reduced $\mathrm{NH}_{3}$ emissions in $\mathrm{E} 2$, the areas under neutral or $\mathrm{NH}_{3}$-poor conditions expanded in particular for January and April. The common $\mathrm{NH}_{3}$-rich condition suggested potentially high sensitivity of SIA formation to $\mathrm{SO}_{2}$ and $\mathrm{NO}_{x}$ emissions.

\subsubsection{Sensitivities of $\mathrm{NH}_{3}$ and $\mathrm{SIA}$ to $\mathrm{SO}_{2}$ and $\mathrm{NO}_{x}$ changes}

Three more cases were developed to test the effect of $\mathrm{SO}_{2}$ and $\mathrm{NO}_{x}$ emission estimates on $\mathrm{NH}_{3}$ and SIA simulation: Cases 1,2 , and 3 assumed $40 \%$ abatement of $\mathrm{SO}_{2}$ emissions, $40 \%$ abatement of $\mathrm{NO}_{x}$ emissions, and $40 \%$ abatement of emissions of both species, respectively. E1 was applied for $\mathrm{NH}_{3}$ emission estimates in all the cases. Table 6 summarizes the modeling performance at JSPAES and SHPD for different cases in October. Clear changes in $\mathrm{NH}_{3}$ and SIA simulation were found with varied $\mathrm{SO}_{2}$ emissions, while the effect of varied $\mathrm{NO}_{x}$ emissions on air quality modeling was much smaller. The bias between the simulation and observation was partly corrected for most cases, indicated by the smaller NMBs. Indicated by NMEs, however, the modeling performance was less conclusive. $\mathrm{NMEs}_{\text {for }} \mathrm{NH}_{4}^{+}$and $\mathrm{SO}_{4}^{2-}$ were reduced for Cases 1 and 3, while increased NMEs were found for $\mathrm{NH}_{3}$ and $\mathrm{NO}_{3}^{-}$. Limitation in the mechanisms of SIA formation can be an important reason for the discrepancy. Under $\mathrm{NH}_{3}$-rich conditions, abatement of $\mathrm{SO}_{2}$ emissions (Case 1) would reduce the formation of $\left(\mathrm{NH}_{4}\right)_{2} \mathrm{SO}_{4}$ and thereby lead to growth of $\mathrm{NH}_{3}$ concentrations. This is consistent with the situation in the North China Plain, another region typically suffering from aerosol pollution in China (Liu et al., 2018). The simulated $\mathrm{NH}_{3}$ concentrations were $10.1 \%$ and $11.7 \%$ larger than those in the base case at JSPAES and SHPD, and the simulated SIAs $\left(\mathrm{NH}_{4}^{+}+\mathrm{SO}_{4}^{2-}+\mathrm{NO}_{3}^{-}\right)$were $7.9 \%$ and $11.0 \%$ smaller than those in the base case at JSPAES and SHPD, respectively. Based on the modeling results in Table 3, as a comparison, the simulated $\mathrm{NH}_{3}$ concentrations with $\mathrm{NH}_{3}$ emissions in E2 were calculated to be $23 \%$ and $28 \%$ smaller than those with E1 at JSPAES and SHPD for October, respectively, and the analogue number 


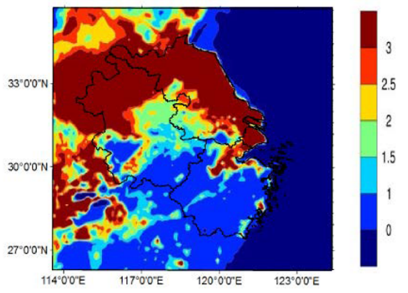

(a) E1 January

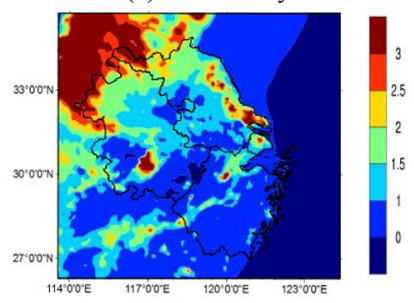

(e) E2 January

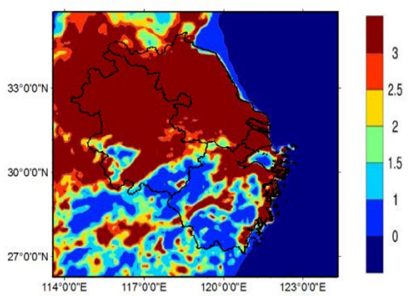

(b) E1 April

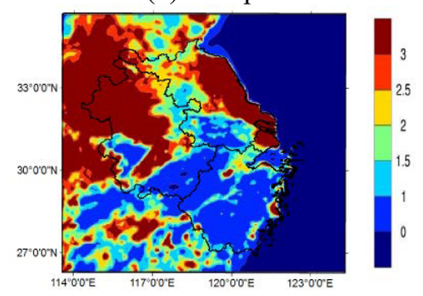

(f) E2 April

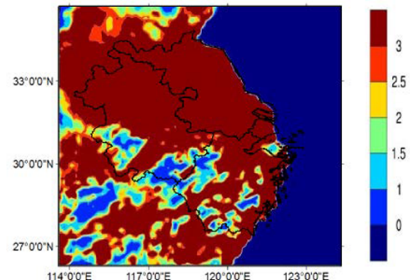

(c) E1 July

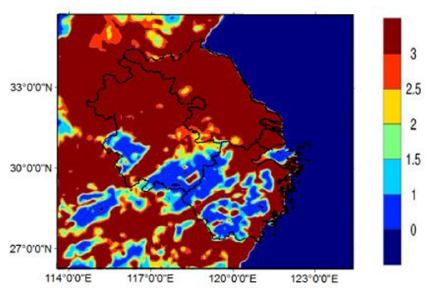

(g) E2 July

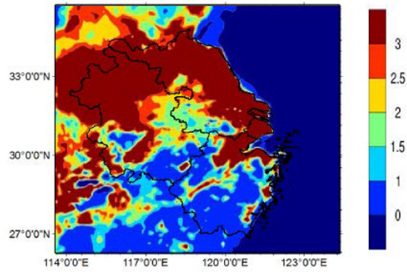

(d) E1 October

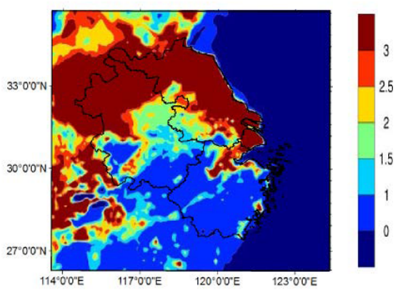

(h) E2 October

Figure 10. The GR values in the YRD region simulated with the two inventories by month.

for SIA concentrations was $5 \%$ at both sites. While the estimation of $\mathrm{NH}_{3}$ emissions played an important role on $\mathrm{NH}_{3}$ simulation, the $\mathrm{SO}_{2}$ estimation could be more effective on SIA simulation. Abatement of $\mathrm{NO}_{x}$ emissions (Case 2) was much less influential. Less $\mathrm{NO}_{x}$ slightly weakened the competition of SIA formation against $\mathrm{SO}_{2}$; thus enhanced formation of $\left(\mathrm{NH}_{4}\right)_{2} \mathrm{SO}_{4}$ and decreased $\mathrm{NH}_{3}$ concentration were simulated at both sites, as shown in Table 6. When $\mathrm{SO}_{2}$ and $\mathrm{NO}_{x}$ were simultaneously reduced in the model (Case 3), similar results were found as with Case 1, implying again that $\mathrm{SO}_{2}$ could be a crucial species in SIA formation in the YRD region. In addition, $\mathrm{NO}_{3}^{-}$aerosols were simulated to grow with the $40 \%$ abatement of $\mathrm{SO}_{2}$ and $\mathrm{NO}_{x}$ emissions, and the benefits of $\mathrm{SO}_{2}$ and $\mathrm{NO}_{x}$ control were partly weakened. To be more effective and efficient in regional air quality improvement, therefore, the control of $\mathrm{NH}_{3}$ emissions should be strengthened along with other pollutants.

\section{Conclusions}

We took the YRD region in eastern China as an example and developed two inventories of $\mathrm{NH}_{3}$ emissions for 2014 based on constant emission factors (E1) and those characterizing agricultural processes (E2). Available information from ground and satellite observations was applied to evaluate the inventories through air quality modeling. Both inventories indicated that agricultural activities (livestock farming and fertilizer use) were the most important sources of $\mathrm{NH}_{3}$, but clear differences exist in estimates and spatial and seasonal distribution of $\mathrm{NH}_{3}$ emissions. The total $\mathrm{NH}_{3}$ emissions in E1 were estimated to be $60 \%$ larger than E2, and the emissions from agriculture in E1 were double those in E2. The information on fertilization season and type from local investigation in E2 resulted in discrepancies in monthly distributions of $\mathrm{NH}_{3}$ emissions from E1, particularly in the northern YRD with abundant croplands. Differences in emission estimates lead to varied $\mathrm{NH}_{3}$ concentrations from CMAQ modeling. At the suburban SHPD site, the overestimation in $\mathrm{NH}_{3}$ concentration from CMAQ with E1 could be largely corrected with $\mathrm{E} 2$, implying the improved estimation of $\mathrm{NH}_{3}$ emissions by E2. At the urban site JSPAES, however, very limited improvement was achieved when E1 was replaced by E2 in the model, indicating that the emission estimation of local urban sources like transportation and residential activities was not improved in E2. Compared to $\mathrm{NH}_{3}$, the modeling performance for SIA is better for most cases, and differences between the simulated concentrations with E1 and E2 were clearly smaller. Application of E2 improved the simulation of $\mathrm{NH}_{4}^{+}$and $\mathrm{SO}_{4}^{2-}$ moderately. For the comparison with the satellite-derived $\mathrm{NH}_{3}$ column, application of $\mathrm{E} 2$ significantly corrected the overestimation in VCD simulation for January and October with E1, but it did not improve the model performance for July. Combining the soil distribution, it can be inferred that the current method might underestimate the $\mathrm{NH}_{3}$ volatilization for acidic soil, particularly in warm seasons. Judged by the simulated GR, most of the YRD region was identified as $\mathrm{NH}_{3}$-rich except for southwest Zhejiang. Through the sensitivity test in which $\mathrm{SO}_{2}$ and $\mathrm{NO}_{x}$ emissions were solely or simultaneously reduced, estimation of $\mathrm{SO}_{2}$ emissions was detected to be more effective in SIA simulation compared to $\mathrm{NH}_{3}$. Reduced $\mathrm{SO}_{2}$ emissions would suppress the formation of $\left(\mathrm{NH}_{4}\right)_{2} \mathrm{SO}_{4}$ and thereby lead to growth of $\mathrm{NH}_{3}$ concentrations. The control of $\mathrm{NH}_{3}$ emissions should be strengthened along with that of $\mathrm{SO}_{2}$ and $\mathrm{NO}_{x}$ for improving the air quality more effectively and efficiently in the region.

This work is a tentative effort on $\mathrm{NH}_{3}$ emission evaluation at the regional scale. The relations between environmental and meteorology conditions and $\mathrm{NH}_{3}$ volatilization were not fully considered, and the bidirectional surface-atmosphere 
Table 6. The modeling performance at JSPAES and SHPD in cases with different $\mathrm{SO}_{2}$ and $\mathrm{NO}_{x}$ emission estimates. The NMBs and NMEs were based on the observed and simulated hourly concentrations.

\begin{tabular}{|c|c|c|c|c|c|c|c|}
\hline & \multirow[b]{2}{*}{ Cases } & \multicolumn{3}{|c|}{ JSPAES } & \multicolumn{3}{|c|}{ SHPD } \\
\hline & & $\begin{array}{r}\text { Increased/ } \\
\text { decreased \% }\end{array}$ & NMB \% & NME \% & $\begin{array}{r}\text { Increased/ } \\
\text { decreased \% }\end{array}$ & NMB \% & NME \% \\
\hline \multirow[t]{4}{*}{$\mathrm{NH}_{3}$} & Base case & & 1.73 & 56.94 & & 32.32 & 98.36 \\
\hline & Case 1 & 10.14 & 11.09 & 59.02 & 11.67 & 47.54 & 102.68 \\
\hline & Case 2 & -1.17 & -0.59 & 57.85 & -0.83 & 29.51 & 96.93 \\
\hline & Case 3 & 8.48 & 9.29 & 59.64 & 11.12 & 44.92 & 100.94 \\
\hline \multirow[t]{4}{*}{$\mathrm{NH}_{4}^{+}$} & Base case & & 15.01 & 42.27 & & 84.45 & 100.23 \\
\hline & Case 1 & -8.67 & 5.19 & 39.24 & -10.99 & 62.53 & 84.93 \\
\hline & Case 2 & 1.87 & 17.55 & 45.40 & 1.40 & 87.40 & 102.37 \\
\hline & Case 3 & -6.95 & 7.33 & 41.85 & -10.36 & 65.69 & 86.27 \\
\hline \multirow[t]{4}{*}{$\mathrm{SO}_{4}^{2-}$} & Base case & & 14.38 & 43.65 & & 91.92 & 110.18 \\
\hline & Case 1 & -17.63 & -4.90 & 40.81 & -19.59 & 54.30 & 82.62 \\
\hline & Case 2 & 2.76 & 18.42 & 43.7 & 1.55 & 94.34 & 112.30 \\
\hline & Case 3 & -14.91 & -1.98 & 39.39 & -18.45 & 55.96 & 83.67 \\
\hline \multirow[t]{4}{*}{$\mathrm{NO}_{3}^{-}$} & Base case & & -6.55 & 44.81 & & 29.46 & 93.69 \\
\hline & Case 1 & 1.25 & -5.92 & 44.52 & 6.30 & 37.56 & 92.51 \\
\hline & Case 2 & 0.86 & -5.85 & 46.71 & -0.43 & 34.61 & 98.52 \\
\hline & Case 3 & 1.85 & -4.90 & 46.51 & 5.78 & 42.85 & 97.19 \\
\hline
\end{tabular}

exchange was not included, resulting in bias in emission estimation. Uncertainties also come from the limitations in ground and satellite observations and the incomplete mechanism of SIA formation in the current air quality model. For better understanding the role of $\mathrm{NH}_{3}$ emissions in regional air quality, more measurements on both sources and ambient concentrations are recommended for the future.

Data availability. The Multi-resolution Emission Inventory for China used in this study was developed by Tsinghua University (Zheng et al., 2018) and can be obtained at http:// www.meicmodel.org/ (MEIC, 2019). The high-resolution inventory for Jiangsu Province was developed by Zhou et al. (2017) and can be accessed at http://www.airqualitynju.com/En/Data/List/ Datadownload (IASI, 2020). The product of daily $\mathrm{NH}_{3}$ VCDs measured through IASI was developed by the research group of Simon Whitburn at Université Libre de Bruxelles and obtained from the ESPRI data center at https://cds-espri.ipsl.upmc. fr/etherTypo/index.php?id=1700\&L=1 (JS inventories, 2020). The two $\mathrm{NH}_{3}$ emission inventories developed in this work (E1 and E2) are available online: http://www.airqualitynju.com/En/Data/ List/Datadownload.

Supplement. The supplement related to this article is available online at: https://doi.org/10.5194/acp-20-4275-2020-supplement.

Author contributions. YZ developed the strategy and methodology of the work and wrote the draft. MY ran the model and produced the figures. $\mathrm{XH}$ revised the method and provided useful comments. $\mathrm{FC}$ and $\mathrm{JZ}$ conducted ground observations of $\mathrm{NH}_{3}$ and aerosols.

Competing interests. The authors declare that they have no conflict of interest.

Special issue statement. This article is part of the special issue "Regional assessment of air pollution and climate change over East and Southeast Asia: results from MICS-Asia Phase III". It is not associated with a conference.

Acknowledgements. This work was sponsored by the Natural Science Foundation of China (91644220 and 41922052) and the National Key Research and Development Program of China (2017YFC0210106). We would like to acknowledge Qizhen Liu and Zhong Zou from the Shanghai Environmental Monitoring Center and Yunhua Chang from Nanjing University of Information Science \& Technology for the ground measurement data, Qiang Zhang from Tsinghua University and Cheng Huang from the Shanghai Research Academy of Environmental Science for emission data, and Simon Whitburn from Université Libre de Bruxelles and Yuanhong Zhao from Peking University for satellite data processing.

Financial support. This research has been supported by the National Natural Science Foundation of China (grant nos. 91644220 and 41922052) and the National Key Research and Development Program of China (grant no. 2017YFC0210106). 
Review statement. This paper was edited by Joshua Fu and reviewed by three anonymous referees.

\section{References}

Ansari, A. S. and Pandis, S. N.: Response of inorganic PM to precursor concentrations, Environ. Sci. Technol., 32, 2706-2714, 1998.

Bash, J. O., Cooter, E. J., Dennis, R. L., Walker, J. T., and Pleim, J. E.: Evaluation of a regional air-quality model with bidirectional $\mathrm{NH}_{3}$ exchange coupled to an agroecosystem model, Biogeosciences, 10, 1635-1645, https://doi.org/10.5194/bg-101635-2013, 2013

Beusen, A. H. W., Bouwman, A. F., Heuberger, P. S. C., van Drecht, G., and van der Hoek, K. W.: Bottom-up uncertainty estimates of global ammonia emissions from global agricultural production systems, Atmos. Environ., 42, 6067-6077, 2008.

Cai, G. X., Chen, D. L., Ding, H., Pacholski, A., Fan, X. H., and Zhu, Z. L.: Nitrogen losses from fertilizers applied to maize, wheat and rice in the North China Plain, Nutr. Cycl. Agroecosys., 63, 187-195, 2002.

Chen, D., Zhao, Y., Lyu, R., Wu, R., Dai, L., Zhao, Y., Chen, F., Zhang, J., Yu, H., and Guan, M.: Seasonal and spatial variations of optical properties of light absorbing carbon and its influencing factors in a typical polluted city in Yangtze River Delta, China, Atmos. Environ., 199, 45-54, 2019.

Chen, X., Walker, J. T., and Geron, C.: Chromatography related performance of the Monitor for AeRosols and GAses in ambient air (MARGA): laboratory and field-based evaluation, Atmos. Meas. Tech., 10, 3893-3908, https://doi.org/10.5194/amt10-3893-2017, 2017.

Cheng, Y., Zheng, G., Wei, C., Mu, Q., Zheng, B., Wang, Z., Gao, M., Zhang, Q., He, K., Carmichael, G., Pöschl, U., and Su, H.: Reactive nitrogen chemistry in aerosol water as a source of sulfate during haze events in China, Sci. Adv., 2, e1601530, https://doi.org/10.1126/sciadv.1601530, 2016.

Cheng, Z., Wang, S., Fu, X., Watson, J. G., Jiang, J., Fu, Q., Chen, C., Xu, B., Yu, J., Chow, J. C., and Hao, J.: Impact of biomass burning on haze pollution in the Yangtze River delta, China: a case study in summer 2011, Atmos. Chem. Phys., 14, 45734585, https://doi.org/10.5194/acp-14-4573-2014, 2014.

Davies, D. K., Ilavajhala, S., Wong, M. M., and Justice, C. O.: Fire Information for Resource Management System: Archiving and Distributing MODIS Active Fire Data, IEEE T. Geosci. Remote, 47, 72-79, 2009.

Dong, W., Xin, J., and Wang, S.: Temporal and spatial distribution of anthropogenic ammonia emissions in China: 1994-2006, Environ. Sci., 31, 1457-1463, 2010 (in Chinese).

Dong, X., Li, J., Fu, J. S., Gao, Y., Huang, K., and Zhuang, G.: Inorganic aerosols responses to emission changes in Yangtze River Delta, China. Sci. Total Environ., 481, 522-532, 2014.

Emery, C., Tai, E., and Yarwood, G.: Enhanced meteorological modeling and performance evaluation for two Texas episodes, Report to the Texas Natural Resources Conservation Commission, prepared by: ENVIRON, International Corp, Novato, CA, 2001.

European Environment Agency (EEA): EMEP/CORINAIR Air Pollutant Emission Inventory Guidebook-2009,
4.D Crop production and agricultural soils, available at: https://www.eea.europa.eu/publications/ emep-eea-emission-inventory-guidebook-2009/ part-b-sectoral-guidance-chapters/4-agriculture/4-d/ 4-d-crop-production-and-agricultural-soils.pdf/view (last access: 25 February 2020), 2009.

European Environment Agency (EEA): EMEP/CORINAIR Air Pollutant Emission Inventory Guidebook-2013, 3.B Manure management, available at: https://www. eea.europa.eu/publications/emep-eea-guidebook-2013/ part-b-sectoral-guidance-chapters/4-agriculture/ 3-b-manure-management/view (last access: 25 February 2020), 2013a.

European Environment Agency (EEA): EMEP/CORINAIR Air Pollutant Emission Inventory Guidebook-2013, 3.D Crop production and agricultural soils, available at: https://www.eea.europa.eu/publications/ emep-eea-guidebook-2013/part-b-sectoral-guidance-chapters/ 4-agriculture/3-d-crop-production/view (last access: 25 February 2020), 2013b.

Fang, X., Shen, G., Xu, C., Qian, X., Li, J., Zhao, Z., Yu, S., and Zhu, K.: Agricultural ammonia emission inventory and its distribution characteristics in Shanghai, Acta Agriculturae Zhejiangensis, 27, 2177-2185, 2015 (in Chinese)

Flechard, C. R., Massad, R.-S., Loubet, B., Personne, E., Simpson, D., Bash, J. O., Cooter, E. J., Nemitz, E., and Sutton, M. A.: Advances in understanding, models and parameterizations of biosphere-atmosphere ammonia exchange, Biogeosciences, 10, 5183-5225, https://doi.org/10.5194/bg-10-5183-2013, 2013.

Fu, X., Wang, S. X., Ran, L. M., Pleim, J. E., Cooter, E., Bash, J. O., Benson, V., and Hao, J. M.: Estimating $\mathrm{NH}_{3}$ emissions from agricultural fertilizer application in China using the bi-directional CMAQ model coupled to an agro-ecosystem model, Atmos. Chem. Phys., 15, 6637-6649, https://doi.org/10.5194/acp-156637-2015, 2015

Fu, X., Wang, S., Xing, J., Zhang, X., Wang, T., and Hao, J.: Increasing ammonia concentrations reduce the effectiveness of particle pollution control achieved via $\mathrm{SO}_{2}$ and $\mathrm{NO}_{X}$ emissions reduction in east China, Environ. Sci. Technol. Lett., 4, 221-227, 2017.

Guenther, A. B., Jiang, X., Heald, C. L., Sakulyanontvittaya, T., Duhl, T., Emmons, L. K., and Wang, X.: The Model of Emissions of Gases and Aerosols from Nature version 2.1 (MEGAN2.1): an extended and updated framework for modeling biogenic emissions, Geosci. Model Dev., 5, 1471-1492, https://doi.org/10.5194/gmd-5-1471-2012, 2012.

Guo, H., Cheng, T., Gu, X., Wang, Y., Chen, H., Bao, F., Shi, S. Y., Xu, B. R., Wang, W. N., Zuo, X., Zhang, X. C., and Meng, C.: Assessment of $\mathrm{PM}_{2.5}$ concentrations and exposure throughout China using ground observations, Sci. Total Environ., 1024, 601$602,2017$.

Gyldenkaerne, S., Skjøth, C., Hertel, O., and Ellermann, T. A.: Dynamical ammonia emission parameterization for use in air pollution models, J. Geophys. Res., 110, D07108, https://doi.org/10.1029/2004JD005459, 2005.

Huo, Q., Cai, X., Kang, L., Zhang, H., Song, Y., and Zhu, T.: Estimating ammonia emissions from a winter wheat cropland in North China Plain with field experiments and inverse dispersion modeling, Atmos. Environ., 104, 1-10, 2015. 
Huang, R., Zhang, Y., Bozzetti, C., Ho, K., Cao, J., Han, Y., Daellenbach, K. R., Slowik, J. G., Platt, S. M., Canonaco, F., Zotter, P., Wolf, R., Pieber, S. M., Bruns, E. A., Crippa, M., Ciarelli, G., Piazzalunga, A., Schwikowski, M., Abbaszade, G., SchnelleKreis, J., Zimmermann, R., An, Z., Szidat, S., Baltensperger, U., EI Haddad, I., and Prevot, A. S. H.: High secondary aerosol contribution to particulate pollution during haze events in China, Nature, 514, 218-222, 2014.

Huang, X., Song, Y., Li, M., Li, J., Huo, Q., Cai, X., Zhu, T., Hu, M., Zhang, H.: A high-resolution ammonia emission inventory in China, Global Biogeochem. Cy., 26, GB1030, https://doi.org/10.1029/2011GB004161, 2012.

IASI: available at: http://www.airqualitynju.com/En/Data/List/ Datadownload, last access: 4 April 2020.

JS inventories: $\mathrm{NH}_{3}$ total column from IASI (Level 2), available at: https://cds-espri.ipsl.upmc.fr/etherTypo/index.php?id= 1700\&L=1, last access: 4 April 2020.

Kang, Y., Liu, M., Song, Y., Huang, X., Yao, H., Cai, X., Zhang, H., Kang, L., Liu, X., Yan, X., He, H., Zhang, Q., Shao, M., and Zhu, T.: High-resolution ammonia emissions inventories in China from 1980 to 2012, Atmos. Chem. Phys., 16, 2043-2058, https://doi.org/10.5194/acp-16-2043-2016, 2016.

Kurokawa, J., Ohara, T., Morikawa, T., Hanayama, S., JanssensMaenhout, G., Fukui, T., Kawashima, K., and Akimoto, H.: Emissions of air pollutants and greenhouse gases over Asian regions during 2000-2008: Regional Emission inventory in ASia (REAS) version 2, Atmos. Chem. Phys., 13, 11019-11058, https://doi.org/10.5194/acp-13-11019-2013, 2013.

Lanciki, A.: 2060 MARGA Monitor for AeRosols and Gases in ambient Air. Metrohm Process Analytics, Switzerland, available at: https://www.metrohm.com/en/products/process-analyzers/ applikon-marga/ (last access: 10 February 2020), 2018.

Li, B., Zhang, J., Zhao, Y., Yuan, S., Zhao, Q., Shen, G., and Wu, H.: Seasonal variation of urban carbonaceous aerosols in a typical city Nanjing in Yangtze River Delta, China Atmos. Environ., 106, 223-231, 2015.

Li, L.: The numerical simulation of comprehensive air pollution characteristics in a typical city-cluster, $\mathrm{PhD}$ thesis, Shanghai University, Shanghai, China, 2012.

Liu, C. and Yao, L.: Agricultural ammonia emission inventory and its distribution characteristics in Jiangsu Province, Journal of Anhui Agricultural Sciences, 44, 70-74, 2016 (in Chinese).

Liu, M., Huang, X., Song, Y., Xu, T., Wang, S., Wu, Z., Hu, M., Zhang, L., Zhang, Q., Pan, Y., Liu, X., and Zhu, T.: Rapid $\mathrm{SO}_{2}$ emission reductions significantly increase tropospheric ammonia concentrations over the North China Plain, Atmos. Chem. Phys., 18, 17933-17943, https://doi.org/10.5194/acp-18-179332018, 2018.

Liu, X., Zhang, Y., Han, W., Tang, A., Shen, J., Cui, Z., Vitousek, P., Erisman, J. W., Goulding, K., Christie, P., Fangmeier, A., and Zhang, F.: Enhanced nitrogen deposition over China, Nature, 494, 459-463, 2013.

MEIC: available at: http://www.meicmodel.org/, last access: 31 July 2019.

Ministry of Environmental Protection (MEP): The Guideline of Emission Inventory Development for Atmospheric Ammonia, 2014 (in Chinese).
National Development and Reform Commission of China (NDRC): National data on the cost and profit of agricultural product, China Statistics Press, Beijing, 2015 (in Chinese).

Pan, Y., Tian, S., Zhao, Y., Zhang, L., Zhu, X., Gao, J., Huang, W., Zhou, Y., Song, Y., Zhang, Q., and Wang, Y.: Identifying ammonia hotspots in China using a national observation network, Environ. Sci. Technol., 52, 3926-3934, 2018.

Pan, Y. P., Wang, Y. S., Tang, G. Q., and Wu, D.: Wet and dry deposition of atmospheric nitrogen at ten sites in Northern China, Atmos. Chem. Phys., 12, 6515-6535, https://doi.org/10.5194/acp12-6515-2012, 2012.

Paulot, F., Fan, S., and Horowitz, L. W.: Contrasting seasonal responses of sulfate aerosols to declining $\mathrm{SO}_{2}$ emissions in the Eastern US: implications for the efficacy of $\mathrm{SO}_{2}$ emission controls, Geophys. Res. Lett., 44, 455-464, https://doi.org/10.1002/2016GL070695, 2017.

Price, C., Penner, J., and Prather, M.: $\mathrm{NO}_{X}$ from lightning, Part I: Global distribution based on lightning physics, J. Geophys. Res.Atmos., 102, 5929-5941, https://doi.org/10.1029/96JD03504, 1997.

Qin, M., Wang, X., Hu, Y., Huang, X., He, L., Zhong, L., Song, Y., Hu, M., and Zhang, Y.: Formation of particulate sulfate and nitrate over the Pearl River Delta in the fall: Diagnostic analysis using the Community Multiscale Air Quality model, Atmos. Environ., 112, 81-89, 2015.

Schaap, M., Otjes, R. P., and Weijers, E. P.: Illustrating the benefit of using hourly monitoring data on secondary inorganic aerosol and its precursors for model evaluation, Atmos. Chem. Phys., 11, 11041-11053, https://doi.org/10.5194/acp-11-110412011, 2011.

Sindelarova, K., Granier, C., Bouarar, I., Guenther, A., Tilmes, S., Stavrakou, T., Müller, J.-F., Kuhn, U., Stefani, P., and Knorr, W.: Global data set of biogenic VOC emissions calculated by the MEGAN model over the last 30 years, Atmos. Chem. Phys., 14, 9317-9341, https://doi.org/10.5194/acp-14-9317-2014, 2014.

Skamarock, W. C., Klemp, J. B., Dudhia, J., Gill, D. O., Barker, D. M., Duda, M. G., Huang, X.-Y., Wang, W., and Powers, J. G.: A Description of the Advanced Research WRF Version 3, NCAR Tech. Note NCAR/TN-475+STR, 113 pp., https://doi.org/10.5065/D68S4MVH, 2008.

Skjøth, C. A., Geels, C., Berge, H., Gyldenkærne, S., Fagerli, H., Ellermann, T., Frohn, L. M., Christensen, J., Hansen, K. M., Hansen, K., and Hertel, O.: Spatial and temporal variations in ammonia emissions - a freely accessible model code for Europe, Atmos. Chem. Phys., 11, 5221-5236, https://doi.org/10.5194/acp-11-5221-2011, 2011.

Stieger, B., Spindler, G., Fahlbusch, B. Muller, K., Gruner, A., Poulain, L., Thoni, L., Seitler, E., Wallasch, M., and Herrmann, H.: Measurements of $\mathrm{PM}_{10}$ ions and trace gases with the online system MARGA at the research station Melpitz in Germany - A five-year study, J. Atmos. Chem., 75, 33-70, 2018.

Su, F., Huang, B., Ding, X., Gao, Z., Chen, X., Zhang, F., Kogge, M., and Römheld, V.: Ammonia volatilization of different nitrogen fertilizer types, Soils, 38, 682-686, 2006 (in Chinese).

Sutton, M., Place, C., Eager, M., Fowler, D., and Smith, R.: Assessment of the magnitude of ammonia emissions in the UnitedKingdom, Atmos. Environ., 29, 1393-1411, 1995. 
Sutton, M. A., Dragosits, U., Tang, Y. S., and Fowler, D.: Ammonia emissions from nonagricultural sources in the UK, Atmos. Environ., 34, 855-869, 2000.

University of North Carolina at Chapel Hill (UNC): Operational Guidance for the Community Multiscale Air Quality (CMAQ) Modeling System Version 4.7.1 (June 2010 Release), available at: http://www.cmaq-model.org (last access: 10 February 2020), 2010.

U.S. Environmental Protection Agency (USEPA): Compilation of Air Pollutant Emission Factors, available at: http://www.epa.gov/ ttn/chief/ap42/index.html (last access: 9 March 2019), 2002.

Van Damme, M., Clarisse, L., Heald, C. L., Hurtmans, D., Ngadi, Y., Clerbaux, C., Dolman, A. J., Erisman, J. W., and Coheur, P. F.: Global distributions, time series and error characterization of atmospheric ammonia $\left(\mathrm{NH}_{3}\right)$ from IASI satellite observations, Atmos. Chem. Phys., 14, 2905-2922, https://doi.org/10.5194/acp14-2905-2014, 2014.

Van Damme, M., Clarisse, L., Dammers, E., Liu, X., Nowak, J. B., Clerbaux, C., Flechard, C. R., Galy-Lacaux, C., Xu, W., Neuman, J. A., Tang, Y. S., Sutton, M. A., Erisman, J. W., and Coheur, P. F.: Towards validation of ammonia $\left(\mathrm{NH}_{3}\right)$ measurements from the IASI satellite, Atmos. Meas. Tech., 8, 15751591, https://doi.org/10.5194/amt-8-1575-2015, 2015.

Warner, J. X., Dickerson, R. R., Wei, Z., Strow, L. L., Wang, Y., and Liang, Q.: Increased atmospheric ammonia over the world's major agricultural areas detected from space, Geophys. Res. Lett., 44, 2875-2884, https://doi.org/10.1002/2016GL072305, 2017.

Wang, G., Zhang, R., Gomez, M. E., Yang, L., Zamora, M. L., Hu, M., Lin, Y., Peng, J., Guo, S., Meng, J., Li, J., Cheng, C., Hu, T., Ren, Y., Wang, Y., Gao, J., Cao, J., An, Z., Zhou, W., Li, G., Wang, J., Tian, P., Marrero-Ortiz, W., Secrest, J., Du, Z., Zheng, J., Shang, D., Zeng, L., Shao, M., Wang, W., Huang, Y., Wang, Y., Zhu, Y., Li, Y., Hu, J., Pan, B., Cai, L., Cheng, Y., Ji, Y., Zhang, F., Rosenfeld, D., Liss, P. S., Duce, R. A., Kolb, C. E., and Molina, M. J.: Persistent sulfate formation from London Fog to Chinese haze, P. Natl. Acad. Sci. USA, 113, 13630-13635, 2016.

Wang, S., Xing, J., Jang, C., Zhu, Y., Fu, J. S., and Hao, J.: Impact assessment of ammonia emissions on inorganic aerosols in east China using response surface modeling technique, Environ. Sci. Technol., 45, 9293-9300, 2011.

Wei, L., Duan, J., Tan, J., Ma, Y., He, K., Wang, S., Huang, X., and Zhang, Y.: Gas-to-particle conversion of atmospheric ammonia and sampling artifacts of ammonium in spring of Beijing, Science China, 45, 216-226, 2015 (in Chinese).

Wichink Kruit, R. J., Schaap, M., Sauter, F. J., van Zanten, M. C., and van Pul, W. A. J.: Modeling the distribution of ammonia across Europe including bi-directional surface-atmosphere exchange, Biogeosciences, 9, 5261-5277, https://doi.org/10.5194/bg-9-5261-2012, 2012.

Xiao, Z. M., Zhang, Y. F., Hong, S. M., Bi, X. H., Jiao, L., Feng, Y. C., and Wang, Y. Q.: Estimation of the main factors influencing haze, based on a long-term monitoring Campaign in Hangzhou, China, Aerosol Air Qual. Res., 11, 873-882, 2011.

Yang, F., Tan, J., Zhao, Q., Du, Z., He, K., Ma, Y., Duan, F., Chen, G., and Zhao, Q.: Characteristics of $\mathrm{PM}_{2.5}$ speciation in representative megacities and across China, Atmos. Chem. Phys., 11, 5207-5219, https://doi.org/10.5194/acp-11-5207-2011, 2011.
Yang, Y. and Zhao, Y.: Quantification and evaluation of atmospheric pollutant emissions from open biomass burning with multiple methods: a case study for the Yangtze River Delta region, China, Atmos. Chem. Phys., 19, 327-348, https://doi.org/10.5194/acp19-327-2019, 2019.

Yang, Z.: Estimation of ammonia emission from livestock in China based on mass-flow method and regional comparison, Master thesis, Peking University, Beijing, China, 2008.

Yu, F., Chao, N., Wu, J., Tang, G., Chen, J., Wang, H., and Wu, Z.: Research on agricultural ammonia emission inventory of Zhejiang Province in 2013, Environmental Pollution \& Control, 38, 41-46, 2016 (in Chinese).

Zhang, F, Chen, X., and Chen, Q.: The fertilization guideline for the main crop types in China, China Agricultural University Press, Beijing, 2009 (in Chinese).

Zhang, L., Chen, Y., Zhao, Y., Henze, D. K., Zhu, L., Song, Y., Paulot, F., Liu, X., Pan, Y., Lin, Y., and Huang, B.: Agricultural ammonia emissions in China: reconciling bottom-up and top-down estimates, Atmos. Chem. Phys., 18, 339-355, https://doi.org/10.5194/acp-18-339-2018, 2018.

Zhang, Q., Zhang, M., Yang, Y., and Lu, J.: Volatilization of ammonium bicarbonate and urea in main soil of Shandong Province, Chinese J. Soil Sci., 33, 32-34, 2002.

Zhang, X., Wu, Y., Liu, X., Reis, S., Jin, J., Dragosits, U., van Damme, M., Clarisse, L., Whitburn, S., Coheur, P. F., and Gu, B.: Ammonia emissions may be substantially underestimated in China, Environ. Sci. Technol., 51, 12089-12096, 2017.

Zhang, X. Y., Wang, Y. Q., Niu, T., Zhang, X. C., Gong, S. L., Zhang, Y. M., and Sun, J. Y.: Atmospheric aerosol compositions in China: spatial/temporal variability, chemical signature, regional haze distribution and comparisons with global aerosols, Atmos. Chem. Phys., 12, 779-799, https://doi.org/10.5194/acp12-779-2012, 2012

Zhang, Y., Dore, A. J., Ma, L., Liu, X., Ma, W., Cape, J. N., and Zhang, F.: Agricultural ammonia emissions inventory and spatial distribution in the North China Plain, Environ. Pollut., 158, 490501, 2010.

Zhang, Y., Bo, X., Zhao, Y., and Nielsen, C. P.: Benefits of current and future policies on emissions of China's coal-fired power sector indicated by continuous emission monitoring, Environ. Pollut., 251, 415-424, 2019.

Zhao, B., Wang, S, Wang, J., Fu, J. S., Liu, T., Xu, J, Fu, X., and Hao, J.: Impact of national $\mathrm{NO}_{x}$ and $\mathrm{SO}_{2}$ control policies on particulate matter pollution in China, Atmos. Environ., 77, 453463, 2013.

Zhao, Y., Qiu, L. P., Xu, R. Y., Xie, F. J., Zhang, Q., Yu, Y. Y., Nielsen, C. P., Qin, H. X., Wang, H. K., Wu, X. C., Li, W. Q., and Zhang, J.: Advantages of a city-scale emission inventory for urban air quality research and policy: the case of Nanjing, a typical industrial city in the Yangtze River Delta, China, Atmos. Chem. Phys., 15, 12623-12644, https://doi.org/10.5194/acp-15-126232015, 2015.

Zhao, Y., Mao, P., Zhou, Y., Yang, Y., Zhang, J., Wang, S., Dong, Y., Xie, F., Yu, Y., and Li, W.: Improved provincial emission inventory and speciation profiles of anthropogenic non-methane volatile organic compounds: a case study for Jiangsu, China, Atmos. Chem. Phys., 17, 7733-7756, https://doi.org/10.5194/acp17-7733-2017, 2017. 
Zheng, H., Cai, S., Wang, S., Zhao, B., Chang, X., and Hao, J.: Development of a unit-based industrial emission inventory in the Beijing-Tianjin-Hebei region and resulting improvement in air quality modeling, Atmos. Chem. Phys., 19, 3447-3462, https://doi.org/10.5194/acp-19-3447-2019, 2019.

Zheng, Z., Weng, J., Wang, S., and Wang, J.: Estimation of ammonia emission in Anhui Province, Journal of Anhui Agricultural Sciences, 8, 73-75, 2016 (in Chinese).

Zheng, B., Tong, D., Li, M., Liu, F., Hong, C., Geng, G., Li, H., Li, X., Peng, L., Qi, J., Yan, L., Zhang, Y., Zhao, H., Zheng, Y., He, K., and Zhang, Q.: Trends in China's anthropogenic emissions since 2010 as the consequence of clean air actions, Atmos. Chem. Phys., 18, 14095-14111, https://doi.org/10.5194/acp-18-140952018, 2018.
Zhong, N., Zeng, Q., Zhang, L., Liao, B., Zhou, X., and Jiang, J.: Effects of acidity and alkalinity on urea transformation in soil, Chinese J. Soil Sci., 37, 1123-1128, 2006 (in Chinese).

Zhou, Y., Zhao, Y., Mao, P., Zhang, Q., Zhang, J., Qiu, L., and Yang, Y.: Development of a high-resolution emission inventory and its evaluation and application through air quality modeling for Jiangsu Province, China, Atmos. Chem. Phys., 17, 211-233, https://doi.org/10.5194/acp-17-211-2017, 2017. 